OECD Environment Working Papers No. 89

\title{
Measuring environmental innovation using patent data
}

\section{Ivan Haščič,}

\section{Mauro Migotto}


Organisation de Coopération et de Développement Économiques

Organisation for Economic Co-operation and Development

22-Jun-2015

ENVIRONMENT DIRECTORATE

English - Or. English

\section{MEASURING ENVIRONMENTAL INNOVATION USING PATENT DATA - ENVIRONMENT WORKING PAPER No. 89}

by Ivan Haščič (1) and Mauro Migotto (1)

OECD Working Papers should not be reported as representing the official views of the OECD or of its member countries. The opinions expressed and arguments employed are those of the author(s).

(1) OECD Environment Directorate

Authorised for publication by Simon Upton, Director, Environment Directorate.

Keywords: innovation, indicators, environmental technologies

JEL classification: $03,031,034,038, Q 2, Q 4, Q 5$

OECD Environment working papers are available at www.oecd.org/env/workingpapers.htm

JT03379232

Complete document available on OLIS in its original format

This document and any map included herein are without prejudice to the status of or sovereignty over any territory, to the delimitation of international frontiers and boundaries and to the name of any territory, city or area. 


\section{OECD ENVIRONMENT WORKING PAPERS}

OECD Working Papers should not be reported as representing the official views of the OECD or of its member countries. The opinions expressed and arguments employed are those of the author(s).

OECD Working Papers describe preliminary results or research in progress by the author(s) and are published to stimulate discussion on a broad range of issues on which the OECD works.

This series is designed to make available to a wider readership selected studies on environmental issues prepared for use within the OECD. Authorship is usually collective, but principal author(s) are named. The papers are generally available only in their original language -English or French- with a summary in the other language.

Comments on Working Papers are welcomed, and may be sent to:

Environment Directorate

OECD, 2 rue André-Pascal, 75775 Paris Cedex 16, France

or by e-mail: env.contact@oecd.org

OECD Environment Working Papers are published on www.oecd.org/env/workingpapers.htm

This document and any map included herein are without prejudice to the status of or sovereignty over any territory, to the delimitation of international frontiers and boundaries and to the name of any territory, city or area.

The statistical data for Israel are supplied by and under the responsibility of the relevant Israeli authorities. The use of such data by the OECD is without prejudice to the status of the Golan Heights, East Jerusalem and Israeli settlements in the West Bank under the terms of international law.

\section{(C) OECD (2015)}

You can copy, download or print OECD content for your own use, and you can include excerpts from OECD publications, databases and multimedia products in your own documents, presentations, blogs, websites and teaching materials, provided that suitable acknowledgment of OECD as source and copyright owner is given.

All requests for commercial use and translation rights should be submitted to rights@oecd.org 


\section{TABLE OF CONTENTS}

ABSTRACT

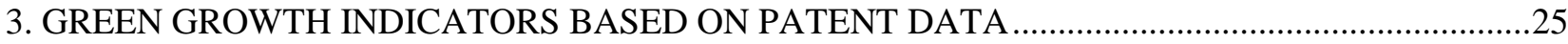

3.1. Indicator of technology development (inventive activity) .............................................................25

3.2. Indicator of international collaboration in technology development (co-invention) .........................31

3.3. Indicator of technology diffusion (market protection) …................................................................33

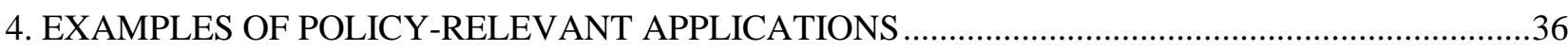

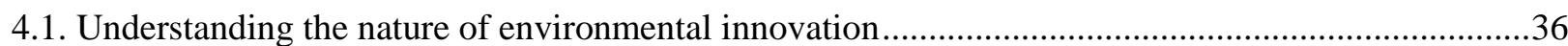

4.2. Assessment of the role of environmental policy in the development of environmental technologies 37

4.3. Assessment of the determinants of international collaboration for environmental technologies.........39

4.4. Assessment of the determinants of market diffusion of environmental technologies.........................40

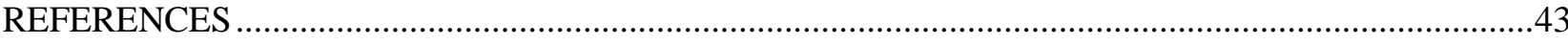

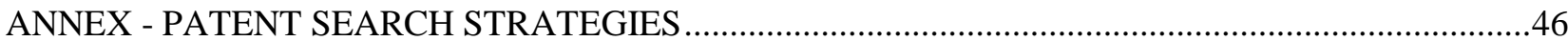

\section{Tables}

Table 1. Innovation indicators currently included in the set of OECD Green Growth indicators.......12

Table 2. Alternative measures of innovation and their key features.................................................17

Table 3. Approximate mapping $\mathrm{b} / \mathrm{w}$ environmental policy priorities and patent search strategies .....20

Table 4. Number of inventions by OECD and G20 countries ....................................................27

Table 5. Most important inventor countries globally in environment related technologies ...............28

Table 6. Specialisation in environment-related technologies ..........................................................29

Table 7. Assessment of inventive activity using alternative metrics (2011) .......................................30

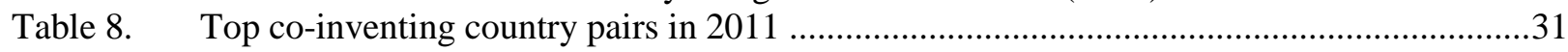


Table 9. Top ten and bottom ten co-invention rates in climate change mitigation technologies.........32

Table 10. Diffusion of waste management technologies, 2011 ..........................................................34

Table 11. Importance of selected jurisdictions for environment-related technologies ...........................35

Table 12. Comparison of the importance of jurisdictions as markets vs inventors ...............................35

\section{Figures}

Figure 1. Inventive activity in selected environment-related technologies.....................................25

Figure 2. Inventive activity: the fastest and slowest growing technologies.....................................26

Figure 3. The innovation-science link in the develoment of environmental technologies....................36

Figure 4. Inventive activity in solid waste management in Germany .................................................37

Figure 5. The choice of policy instruments matters: Estimated effect on inventive activity .................38

Figure 6. The need for a policy mix targeting innovations in vehicle propulsion technologies ............38

Figure 7. Policy predictability: Estimated effect of volatility in public R\&D on inventive activity ....39

Figure 8. Relative preponderance of water-related adaptation patents ..............................................41

Figure 9. Relative preponderance of water-related patents and water vulnerability ...........................41

Figure 10. Encouraging diffusion of wind power technologies ...................................................42 


\begin{abstract}
This paper refines indicators to measure innovation in environment-related technologies, drawing on recent methodological advances that allow a more accurate assessment of environment-related innovation in a broader range of countries and covering a greater variety of the relevant technologies. Three indicators are discussed in the paper: an indicator of technology development (a measure of inventive activity) in over 80 specific environmental technologies; an indicator of international collaboration in technology development (a measure of co-invention); and an indicator of technology diffusion (a measure of market protection). These indicators provide a range of tools for assessing innovative performance in country and policy studies. The indicators are based on patent data because they have a number of attractive properties compared to other alternatives: they are widely available, quantitative, commensurable, output-oriented and capable of being disaggregated - an important advantage when analysing environmental technologies. At the same time, not all innovations or inventions are patented, and measuring the number of patents by itself does not provide an indication of their relative importance and impact. Techniques have been developed to overcome these limitations, yet it is important to carefully interpret patent-based indicators.
\end{abstract}

Keywords: innovation, indicators, environmental technologies

JEL classification: O3; O31; O34; O38; Q2; Q4; Q5

\title{
RÉSUMÉ
}

Cet article peaufine des indicateurs qui mesurent l'innovation dans les technologies liées à l'environnement, en puisant dans des progrès méthodologiques récents qui permettent une évaluation plus précise de l'innovation environnementale dans un nombre plus grand de pays et couvrant une plus grande variété de technologies. Trois indicateurs sont traités dans cet article: un indicateur de développement technologique (une mesure d'activité inventive) ventilé par plus de 80 technologies environnementales ; un indicateur de collaboration internationale dans le développement technologique (une mesure de coinvention); et un indicateur de diffusion technologique (une mesure de protection du marché). Ces indicateurs fournissent des outils pour évaluer les performances en matière d'innovation dans les études par pays et les analyses de politiques. Ces indicateurs sont basés sur les brevets parce que ceux-ci possèdent plusieurs avantages par rapport aux autres mesures: les données sont disponibles, quantitatives, commensurables, axées sur les résultats et peuvent être désagrégées - un avantage important quand il s'agit d'analyser les technologies environnementales. Cependant, les innovations et les inventions ne sont pas toutes brevetées, et le comptage des brevets ne suffit pas en soi à donner une idée de leur importance et impact. Des méthodologies ont été développées pour surmonter ces limitations, mais les indicateurs de brevets doivent être interprétés avec prudence.

Mots-clés : innovation, indicateurs, technologies environnementales

Classification JEL : O3; O31; O34; O38; Q2; Q4; Q5 


\section{FOREWORD}

This paper is a contribution to support the development of the OECD set of Green Growth Indicators. It has been authored by Ivan Haščič and Mauro Migotto (OECD Environment Directorate). A draft of the paper was reviewed by the OECD Working Party on Environmental Information (WPEI) in November 2014 and benefited from the comments received. The authors are grateful to Nick Johnstone and Hélène Dernis (OECD Directorate for Science, Technology and Innovation) for helpful comments on a previous version of this paper, and to Jennifer Humbert for editorial assistance. 


\section{EXECUTIVE SUMMARY}

Policy makers are interested in measuring environmental innovation for several reasons; to monitor its potential to reduce the negative environmental impacts of economic activity at lower cost; to evaluate the effectiveness of policies to promote environmental innovation; and to assess new business opportunities and emerging markets. It is widely acknowledged that far-reaching innovation will be needed to address climate change and other environmental challenges, and to accelerate the transition to green growth. Accordingly, environment-related innovation (and innovation in general) was included in the OECD set of Green Growth indicators under the heading of economic opportunities. The indicators were expected to be refined in light of further analytical work.

This paper supports these efforts and develops three indicators to be included in the OECD set of Green Growth indicators: an indicator of technology development (a measure of inventive activity) in over 80 specific environmental technologies; an indicator of international collaboration in technology development (a measure of co-invention); and an indicator of technology diffusion (a measure of market protection).

These indicators provide a range of tools for assessing countries' innovative performance, for example as part of the OECD Environmental Performance Reviews and Economic Surveys, as well as the innovation- and energy-focused country reviews conducted by the OECD and the IEA. The indicators will also be of use in the OECD's analytical work, such as the assessment of the various market and policy determinants of innovation, including those directed at development and diffusion of environmental technologies.

This paper uses patent data because they have a number of attractive properties compared to other alternatives: they are widely available, quantitative, commensurable, output-oriented and capable of being disaggregated - an important advantage when analysing environmental technologies. At the same time, not all innovations or inventions are patented, and measuring the number of patents by itself does not provide an indication of their relative importance and impact. Techniques have been developed to overcome these limitations, yet it is important to carefully interpret patent-based indicators. 


\section{ACRONYMS}

CCMT Climate Change Mitigation Technologies

CPC Cooperative Patent Classification

ECLA European Patent Classification

ENVTECH Environment-related Technologies (as defined by patent search strategies presented here)

EPO European Patent Office

HVAC Heating, Air Conditioning and Ventilation

IPC International Patent Classification

JPO Japan Patent Office

PATSTAT Worldwide Patent Statistical Database

PCT Patent Co-operation Treaty

PF1 Patent family of size 1 and greater (i.e. all patent priorities, all inventions)

PF2 Patent family of size 2 and greater (i.e. only 'claimed' priorities, a subset of inventions)

R\&D Research and Development

RTA Relative Technological Advantage

USPC United States Patent Classification

USPTO United States Patent and Trademark Office

WIPO World Intellectual Property Organisation 


\section{GLOSSARY OF RELEVANT TERMS}

Application (or filing) date: The patent application date is the date on which the patent office received the patent application.

Application for a patent: To obtain a patent, an application must be filed with the authorised body (patent office, or application authority) with all the necessary documents and fees. The patent office will conduct an examination to decide whether to grant or reject the application.

Claimed priority: A priority application that has been duplicated at a foreign patent office at least once. An international patent family with at least two members.

Duplicate: See "equivalent".

ECLA: The European Patent Office's patent classification system. It is based on the IPC Classification System, with greater disaggregation.

Equivalent: A patent that relates to the same invention and shares the same priority as a patent from a different issuing authority. The set of such patents, plus the priority, constitute a "simple" patent family. Also referred to as "duplicate".

European Patent Office (EPO): The European Patent Office (a regional patents office) was created to grant European patents, based on a centralised examination procedure. By filing a single European patent application in one of the three official languages (English, French and German), it is possible to obtain patent rights in all the EPC member and extension countries. However, translation in local language may be required in order to "validate" the patent in an EPO member country. The EPO is not an institution of the European Union.

Home bias: Propensity for the priority country to be the same as the inventor or applicant country.

International patent application: Patent applications filed under the Patent Cooperation Treaty (PCT) are commonly referred to as international patent applications. However, an international patent (PCT) application does not result in the issuance of "international patents", i.e. at present there is no global patent system that is responsible for granting international patents. The decision of whether to grant or reject a patent application filed under the PCT rests with the national or regional patent offices.

International Patent Classification (IPC): The International Patent Classification, which is commonly referred to as the IPC, is based on an international multilateral treaty administered by WIPO. The IPC is an internationally recognised patent classification system, which provides a common classification for patents according to technology groups. IPC is periodically revised in order to improve the system and to take account of technical development.

Inventor country: Country of the residence of the inventor, which is frequently used to count patents in order to measure inventive performance.

Japan Patent Office (JPO): The JPO administers the examination and granting of patent rights in Japan. The JPO is an agency of the Ministry of Economy, Trade and Industry (METI). 
Novelty: If an application for a patent is to be successful, the invention must be novel (new). The invention must never have been made public in any way, anywhere, before the date on which the application for a patent is filed (or before the priority date). Obviousness: The concept that the claims defining an invention in a patent application must involve an inventive step if, when compared with what is already known (i.e. prior art), it would not be obvious to someone skilled in the art.

Paris Convention: The Paris Convention for the Protection of Industrial Property was established in 1883 and is generally referred to the Paris Convention. The Paris Convention established the system of priority rights. Under the priority rights, applicants have up to 12 months from first filing their patent application (usually in their own country) in which to make further applications in member countries and claim the original priority date.

Patent Co-operation Treaty (PCT): Signed in 1970, the PCT entered into force in 1978. The PCT provides the possibility to seek patent rights in a large number of countries by filing a single international application (PCT application) with a single patent office (receiving office). The PCT procedure consists of two main phases: a) an "international phase"; and b) a PCT "national/regional phase". PCT applications are administered by the World Intellectual Property Organisation (WIPO).

Patent family: A patent family is a set of individual patents covering different geographical regions, that is, all the equivalent patent applications deposited at various patent offices corresponding to a single invention. Patent family size is a measure of the geographical breadth for which protection of the invention is sought. Several definitions of patent family exist, including "simple" and "extended".

Patent: A patent is an intellectual property right issued by authorised bodies to inventors to make use of, and exploit their inventions for a limited period of time (generally 20 years). The patent holder has the legal authority to exclude others from commercially exploiting the invention (for a limited time period). In return for the ownership rights, the applicant must disclose the invention for which protection is sought. The trade-off between the granting of monopoly rights for a limited period and full disclosure of information is an important aspect of the patenting system.

Patentability: Patentability is the ability of an invention to satisfy the legal requirements for obtaining a patent. The basic conditions of patentability, which an application must meet before a patent is granted, are that the invention must be novel, contain an inventive step (or be non-obvious), be capable of industrial application and not be in certain excluded fields (e.g. scientific theories and mathematical methods are not regarded as inventions and cannot be patented at the EPO).

PATSTAT: The EPO's Worldwide Patent Statistical Database.

Petty patent: see "Utility model".

Prior art: Previously used or published technology that may be referred to in a patent application or examination report: a) in a broad sense, technology that is relevant to an invention and was publicly available (e.g. described in a publication or offered for sale) at the time an invention was made; and b) in a narrow sense, any such technology which would invalidate a patent or limit its scope. The process of prosecuting a patent or interpreting its claims largely consists of identifying relevant prior art and distinguishing the claimed invention from that prior art.

Priority country (office): Country (office) where the patent is first filed before being (possibly) extended to other countries. 
Priority date: The priority date is the first date of filing of a patent application, anywhere in the world (often the applicant's domestic patent office), to protect an invention. The priority date is used to determine the novelty of the invention, which implies that it is an important concept in patent procedures. For statistical purposes, the priority date is the closest date to the date of invention.

Publication lag: In most countries, a patent application is published 18 months after the priority date. For example, all pending EPO and JPO patent applications are published 18 months after the priority date. Prior to a change in rules under the American Inventors Protection Act of 1999, USPTO patent applications were held in confidence until a patent was granted. Patent applications filed at the USPTO on or after 29 November 2000 are to be published 18 months after the priority date, unless requested otherwise by the applicant.

Singleton: A priority patent application that has never been duplicated abroad (it has not been "claimed" as a priority). A one-member patent family.

United States Patent and Trademark Office (USPTO): The USPTO administers the examination and granting of patent rights in the United States. It falls under the jurisdiction of the US Department of Commerce.

Utility model: Also known as "petty patent", these are available in some countries (e.g. Japan). This type of patent involves a simpler inventive step than that in a traditional patent and it is valid for a shorter time period.

World Intellectual Property Organisation (WIPO): An intergovernmental organisation responsible for the negotiation and administration of various multilateral treaties dealing with the legal and administrative aspects of intellectual property. In the patent area, the WIPO is notably in charge of administering the Patent Co-operation Treaty (PCT) and the International Patent Classification system (IPC). It is important to note that WIPO is not a patent granting authority.

Source: Adapted from OECD (2011). 


\section{INTRODUCTION}

The key motivation for measuring environmental innovation is its potential to reduce the negative environmental impacts of economic activity at lower cost. It is widely acknowledged that far-reaching innovation will be needed to address climate change and other environmental challenges. This may lead to the creation of new business opportunities and markets. Accordingly, environment-related innovation was included in the set of OECD Green Growth indicators under the heading of economic opportunities. ${ }^{1}$

The interest by policy-makers in innovation arises from the premise that public policy is able to influence not only the rate but also the direction of innovation. In fact, any government policy will, to some extent, affect the economic environment of firms by changing the opportunity costs of production, and induce innovative responses. The question is how can public environmental policy "bend" the direction of innovation towards more environmentally benign ends (environmental effectiveness), and how such intervention can be done in a manner that generates least cost to society (static cost-efficiency). The interest of policy-makers in the development and wide diffusion of environment-related technologies (or "environmental" technologies as a shorthand) is thus motivated by their potential to render environmental policies more effective and more cost-efficient. Some governments are also motivated by the goal of creating new business opportunities and markets, and thereby accelerating the transition to green growth (dynamic efficiency). Appropriate indicators of the results of innovation can also assist in evaluating the inputs to, and organisation of, the innovation process.

This paper first provides a brief overview of the various approaches to the measurement of environmental innovation, and argues that measures based on patent data are a particularly promising and increasingly used option. It then presents succinctly the methodology for using patent data for the construction of analytically sound and policy relevant indicators. An in-depth discussion of the methodology is provided in a companion paper (Haščič et al. 2015). The third part of the paper focuses on the use of environmental innovation indicators for policy purposes.

Currently, the OECD Green Growth Indicators comprise a limited set of indicators of technology and innovation based on patent data, included under the theme of "Economic opportunities and policy responses" (Table 1). These indicators were expected to be refined in light of further analytical work. The present paper supports these efforts and develops three new indicators to be included in the OECD set of Green Growth indicators.

Table 1. Innovation indicators currently included in the set of OECD Green Growth indicators

Economic opportunities and policy responses

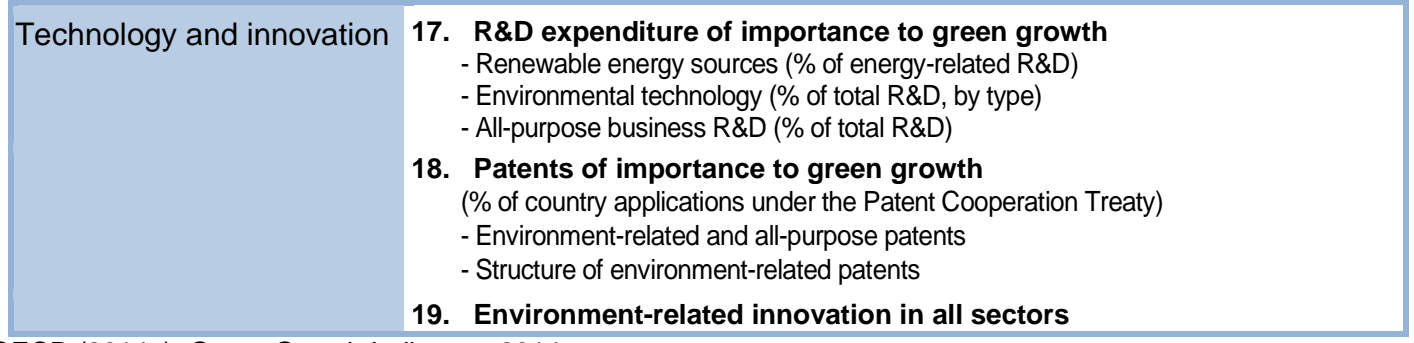

Source: OECD (2014a), Green Growth Indicators 2014.

\footnotetext{
${ }^{1}$ http://www.oecd.org/greengrowth/greengrowthindicators.htm
} 
The indicators presented here could support OECD's country review efforts more broadly, and could be useful for the OECD Environmental Performance Reviews, the OECD Economic Surveys as well as the OECD Reviews of Innovation Policy and the IEA Country Reviews. The consideration of using patentbased indicators as measures of societal responses in country reviews is consistent with the OECD Core Set of Environmental Indicators [ENV/EPOC/WPEI(2013)2]. ${ }^{2}$

This paper presents new and improved patent-based indicators. The improvements extend in three directions - the patent statistics used, the indicators constructed, and the range of environmental technologies covered. First, improved patent statistics are used for the calculation of indicators of inventive activity. Previously, the counts of applications filed under the Patent Cooperation Treaty (PCT) were often used for this purpose. ${ }^{3}$ While this choice was justified in the past, a PCT count presents at least two major drawbacks - (i) it is a partial measure of inventive activity because only a fraction of inventions seek protection through the PCT route; and (ii) it does not provide information about technology diffusion, that is, markets where patent protection for these inventions is sought. Recent methodological developments allow patent statistics to be constructed that are more encompassing - they measure the entire known population of inventions worldwide, they allow differentiation by quality, and they also unequivocally measure (patented) invention as distinct from market protection (through patents). These features allow more accurate and more policy-relevant indicators to be constructed.

Second, in addition to indicators of technology development (inventive activity), the indicator set is expanded to include indicators of international collaboration in technology development (co-invention) and indicators of technology diffusion (protection of markets for technological innovations).

Third, building on recent developments in patent classification systems the search strategies are expanded to allow a broader set of environmental technologies to be identified. The expansion includes a slightly extended set of climate change mitigations technologies (CCMT) in the energy sector, a substantial expansion of CCMTs in the transport and buildings sectors, and an entirely new set of water-related adaptation technologies.

In sum, the following indicators are proposed for inclusion in the set of OECD Green Growth indicators:

- Indicator of technology development (inventive activity) by all countries, in over 80 specific environmental technologies;

- Indicator of international collaboration in technology development (co-invention) by all countries, in several aggregated technological fields;

- Indicator of technology diffusion (market protection) by all countries, in over 80 specific environmental technologies.

\footnotetext{
${ }^{2}$ http://www.oecd.org/env/indicators

${ }^{3}$ The Patent Co-operation Treaty (PCT), in force since 1978, provides the possibility to seek patent rights in multiple countries by filing a single international application (PCT application) with a single patent office (receiving office). Patent applications filed under the PCT are commonly referred to as international patent applications, however, they do not result in the issuance of "international patents" (at present, there is no global patent system). The decision of whether to grant or reject a patent application filed under the PCT rests with the national or regional patent offices to which a PCT application is transferred for consideration upon the request of the applicant (OECD 2009).
} 
Each of these indicators can be expressed as (i) simple count, (ii) share on total, and (iii) relative to a global context (e.g. as metrics of relative technological advantage or relative preponderance). Expressing the inventive (patenting) activity in relation to socio-economic variables (GDP, population, R\&D spending) would also be informative, especially in the green growth context.

\section{CONCEPTUAL APPROACH AND METHODOLOGY}

\subsection{Measuring environmental innovation}

There are a number of candidates for the measurement of innovation but they are not all equally suitable to measure "environmental" innovation. Most commonly, research and development (R\&D) expenditure or the number of scientific personnel in different industries are frequently used as innovation indicators (see OECD 2014b, Main Science and Technology Indicators). Currently the only source of country-level statistics on "environmental" R\&D are data on government budget appropriations and outlays for $R \& D$ (GBAORD) by socio-economic objective, including expenditures directed at "environment" and "energy". ${ }^{4}$ Within the domain of energy, data are available on public spending on energy technology $R \& D$ (see OECD/IEA Energy Technology $R \& D$ Statistics) that is disaggregated into a number of categories including expenditure directed at energy generation from fossil, nuclear and renewable sources; energy storage, hydrogen and fuel cells; as well as energy efficiency in industry, residential and commercial uses, and transportation.

Although such indicators reflect an important element of the overall innovation system, there are a number of disadvantages associated with their use as indicators of innovation. For example, the data are only available at an aggregate level and (with the exception of the energy sector) they cannot be broken down by technology group. Further, the data are incomplete with respect to private R\&D expenditures: currently data on gross domestic expenditure on R\&D (GERD) by socio-economic objective is the only source of data on private $R \& D$ expenditures (incl. business enterprise, higher education, private non-profit) by socio-economic objective (incl. environment, energy). Similar data for energy technology R\&D by the private sector are not available. In either case the data is available only for OECD (IEA) member countries and a number of data gaps exist. Perhaps most significantly, $R \& D$ expenditures are measures of inputs to the innovation process, whereas an "output" measure of innovation would be preferable.

Given these shortcomings, several micro-level data collection efforts have been undertaken which have sought to measure innovation outputs. For instance, in the European Union, a small number of "environment-related" questions have been applied as part of the Community Innovation Survey (CIS). The OECD project on "Environmental Policy and Firm-Level Management" (Johnstone 2007) collected data on input measures of environmental innovation, such as expenditures on environment-related $R \& D$, as well as on output measures such as "clean production" and "product design".

The main shortcoming with such exercises is their cost. A dedicated industrial survey which addresses environmental concerns on a periodic basis would be prohibitively expensive. While some countries do have "environmental" components in their standard industrial censuses or innovation surveys (for example, Canada, Norway, Japan), these data are not comparable across countries, and therefore cannot be used to develop indicators across countries. Moreover, the data are self-reported, while an "objective" measure of innovation would be preferable.

\footnotetext{
${ }^{4}$ See the OECD Frascati Manual (OECD 2002) for the definition of how R\&D expenditure is assigned among the different socio-economic objectives.
} 
Another option for deriving indicators of innovation is administrative data. One possibility would be the development of indicators based upon existing industry and commodity classifications - which have been developed to measure the output of goods and services. To the extent that new technologies are contained in direct (embodied) form in goods and services that are produced, such forms of innovation would be reflected in the underlying data. Doing so would first require identification of industry or commodity classes which represent "environmental" technologies. However, as explained in OECD (2011) currently neither of these classifications is suitable for this purpose: Industry classifications, such as the ISIC, NACE or NAICS, do not lend themselves to identification of "environmental industry activities", except in very specific areas such as water supply, wastewater treatment, and solid waste treatment and disposal (see OECD/Eurostat Manual 1999). Moreover, such categories relate primarily to "end-of-pipe" solutions to environmental concerns which are a limited and comparatively less cost-effective sub-set of the total.

Commodity classifications cannot be used to develop indicators of "environmental innovation", for two key reasons: (i) commodity classifications, such as the Harmonised System, do not lend themselves to the identification of goods and services with reduced negative environmental consequences. In most cases, the classes used are rather broad (the potential candidate classes include goods which have no specific environmental implications or, worse, they include goods which may well be the "dirty" substitutes for environmental innovations); (ii) Most importantly, even if the granularity of the classification system were sufficient to reliably identify the "environmental" goods and services, this in itself would not provide any particular indication of the amount of "innovation" that such a good represents. It is impossible to make a distinction between standardised goods and services which have been on the market for some time, and those which represent real technological innovations and will likely represent only a small percentage of production and trade (see OECD 2011 for a more in-depth discussion).

There are two sources of possible "output" indicators of innovation which address both of these concerns: bibliometric data (scientific publications) and technometric data (patent publications). The use of bibliometric data has been examined extensively in the literature. The potential for bibliometric searches to identify "environmental" innovations arises from the possibility of using keywords (on titles, abstracts, journals or book series) and indexing codes in the searches of relevant databases (for example, the Science Citation Expanded Index, the SCOPUS database, etc.). Data on author, affiliation, date of publication, etc. can be extracted, and counts can be developed to assess the relative innovative activity (see Meyer 2002; Poirier et al. 2015).

Indicators based on bibliometric data are particularly useful for analysing the diffusion of knowledge among inventors (and between countries), based on information on co-publications and citations. The major shortcoming is that while bibliometric data is indeed an intermediate "output" indicator of innovation, it is an ambiguous indicator of market output. Publication in a peer-reviewed journal reflects a scientific advance, but not necessarily one which has commercial applications. It is therefore difficult to use citations even as an index of quality, let alone of actual economic importance.

\section{Patents as a measure of innovation}

Patent data have often been used as a measure of technological innovation because they focus on outputs of the inventive process (Griliches 1990; OECD 2009). Patent data provide a wealth of information on the nature of the invention, the inventor(s) and the applicant, the data is readily available (if not always in a convenient format) and discrete (and thus easily subject to the development of indicators). Significantly, there are very few examples of economically significant inventions which have not been patented (Dernis et al. 2001). 
Patent data present a number of advantages compared to other alternative measures of innovation, notably:

a) they are commensurable because patents are based on an objective standard - the type of invention that can be patented is well-defined; it must satisfy the following three patentability criteria: novel, non-obvious (inventive step) and useful (with industrial application);

b) they measure the intermediate outputs of the inventive process (in contrast to data on $\mathrm{R} \& \mathrm{D}$ expenditures that only measure the input, or data on trade in commodities that do not necessarily embody any innovative technologies);

c) the data are quantitative (and hence easily amenable to statistical analysis); and

d) the data are widely available (not proprietary but in the public domain; in contrast to licensing data for instance);

e) the data can be disaggregated into specific technological fields - a key feature if we are to study "environmental" innovation.

However, it is important to recognise that patents cannot be used to develop a comprehensive measure of innovation. The three commonly listed reasons are:

a) not all innovations are patentable - patents are designed to only protect technological innovations and only those that meet the three patentability criteria listed above. This has implications for the nature of innovations one can measure using patent data; for example, organisational, managerial and non-technological innovations cannot be measured;

b) not all patentable inventions are patented - other intellectual property rights (IPR) regimes exist to protect other kinds of innovations such as copyrights, trademarks and industrial designs. Moreover, an inventor might pursue a more informal strategy to protect technological inventions such as industrial secrecy, lead time, or purposefully complex technical specifications. Surveys of inventors indicate that the rate at which new inventions are patented (propensity to patent) varies across industrial sectors, countries, and over time;

c) patented inventions vary in quality - patenting is costly because significant fees are associated with examination of a patent application, granting of a patent and its renewal; therefore, it is safe to assume that, at least in the expectations of the applicant or patent holder, the prospects for commercialisation and adoption are good. However, not all patented inventions are eventually commercialised and adopted, and as a result the economic value of patents varies.

Economists have developed tools to mitigate these limitations using econometric methods and careful construction of indicators. ${ }^{5}$ These aspects are briefly reviewed in Section 3. A detailed discussion is included in a companion paper (Haščič et al. 2015).

It should also be noted that patent applications are typically disclosed 18 months after the filing date, leading to a "publication lag" in the production of patent-based indicators. ${ }^{6}$

\footnotetext{
${ }^{5}$ For instance, in empirical analyses it is important to control statistically for differences in the propensity to patent, the scope of the patent claims, the value of the patent, and other factors which vary across countries, time and technology fields.

${ }^{6}$ To improve their timeliness, the OECD Directorate for Science, Technology and Innovation publishes now-casted estimates for some of its indicators, and a similar method could be used to now-cast some of the aggregate indicators based on environmental patents.
} 


\section{Patents as a measure of environmental innovation}

Among the various alternatives reviewed here, patent data are best suited for identifying specifically "environmental" innovation. Most importantly, patent classification systems are "technological" by nature (unlike commodity and industry classifications) and allow for a rich characterisation of relevant technologies by describing the engineering features of an invention and its applications at a fine level of detail. For example, the International Patent Classification (IPC) system includes over 70,000 separate technological classes, and the Cooperative Patent Classification (CPC) system - an extension of the IPC has over 200,000 technology classes.

Consequently, patent data allow very specific "environmental" technologies to be identified - for example, a distinction can be drawn between air pollution control devices designed to reduce NOx emissions and devices designed to control $\mathrm{SO}_{2}$ emissions. In addition, each patent application can be classified in multiple classes (unlike commodity or sectoral classifications), which allows for refined searches when inventions are horizontal in nature (e.g. fuel cells for mobile uses). And finally, keyword searches can be used to refine the searches.

Table 2 summarises the key advantages and limitations of the various measures of innovation.

Table 2. Alternative measures of innovation and their key features

\begin{tabular}{|c|c|c|}
\hline Stage of innovation cycle & Measures & Pros and cons \\
\hline \multirow[t]{3}{*}{ "Technology development } & $\begin{array}{l}\text { R\&D expenditures } \\
\text { and personnel }\end{array}$ & $\begin{array}{l}\text { (+) ease of communication } \\
\text { (-) input measure of innovation } \\
\text { (-) difficult to identify "environmental" activities } \\
(-) \text { data availability: only OECD countries and some } \\
\text { sectors }\end{array}$ \\
\hline & Scientific publications & $\begin{array}{l}\text { (+) geographical and temporal coverage } \\
( \pm) \text { possible to identify some "environmental" } \\
\text { aspects }\end{array}$ \\
\hline & Patented inventions & $\begin{array}{l}\text { (+) measures innovation by definition } \\
(+) \text { measures (intermediate) outputs of innovation } \\
\text { (+) granularity, possible to identify specific } \\
\text { "environmental" aspects }\end{array}$ \\
\hline \multirow[t]{2}{*}{ Technology diffusion } & Patenting activity & $\begin{array}{l}(+) \text { global coverage, long time series } \\
(-) \text { captures only technological innovation } \\
(-) \text { timeliness }\end{array}$ \\
\hline & International trade & $\begin{array}{l}\text { (-) difficult to identify "environmental" commodities } \\
(-) \text { most of traded goods are not innovative products }\end{array}$ \\
\hline \multirow[t]{2}{*}{ Technology adoption } & Licensing surveys & $\begin{array}{l}(+) \text { measure of value of innovation (royalties) } \\
(-) \text { cost, confidentiality }\end{array}$ \\
\hline & $\begin{array}{l}\text { Sales and market } \\
\text { penetration }\end{array}$ & $\begin{array}{l}\text { (+) proxy for improvements in environmental } \\
\text { endpoints } \\
(-) \text { availability, confidentiality }\end{array}$ \\
\hline $\begin{array}{l}\text { Non-technological } \\
\text { innovations }\end{array}$ & Innovation surveys & $\begin{array}{l}\text { (+) can measure organisational and managerial } \\
\text { innovations } \\
(-) \text { availability, cost, comparability }\end{array}$ \\
\hline
\end{tabular}




\subsection{Identification of environment-related technologies using patent data}

There are three possible ways of identifying relevant patents:

i) searches based on patent classifications - such as the IPC, CPC, etc. (discussed below) - is the most common approach because it is based on the detailed knowledge of patent examiners;

ii) searches based on keywords in titles or abstracts - this option is typically used in cases when it is difficult to identify relevant and "clean" patent classifications. However, a major drawback of using keywords is that the outcome is sensitive to the language used, and in practice it is often costly to design search strategies in multiple languages. This might lead to a "linguistic" bias for small countries or less frequently used languages. For this reason, the keyword approach is less suitable for international comparisons and cross-country analyses.

iii) manual selection - its major limitation is the cost of conducting the searches - both in terms of time and expert knowledge of the technologies - which renders this method unsuitable for large-scale analyses involving many countries and many technological fields. ${ }^{7}$

Past OECD work has, almost exclusively, relied on searches based on patent classifications. Accordingly this is the best basis on which to construct patent-based indicators for the set of OECD Green Growth indicators.

\section{Patent classification systems}

The International Patent Classification (IPC) system, developed at the World Intellectual Property Organisation (WIPO), is a hierarchical system classifying inventions into more than 70000 technological groups and subgroups. ${ }^{8}$ It is periodically revised in order to reflect the latest technological advances. Patent offices sometimes use their own classification systems to complement the use of the IPC. For example, the former European classification system (ECLA) was an extension of the IPC with about twice as many classification codes. Patent examiners at the European Patent Office (EPO) also used a further extension of the ECLA referred to as in-computer-only (ICO) codes. Other classification systems include the US patent classification (USPC) or the Japanese F-terms.

Recently, the EPO and USPTO have agreed to harmonise their patent classification practices and have developed the Cooperative Patent Classification (CPC) system. ${ }^{9}$ The CPC builds on the ECLA and it integrates elements of the USPC. The CPC is thus an extension of the IPC, allowing the hierarchy of IPC classes to be disaggregated into much greater detail (over 200,000 classification symbols). ${ }^{10}$ The indicators presented in this paper rely on search strategies based on IPC and CPC symbols.

\footnotetext{
${ }^{7}$ One can of course use a combination of the above approaches. In fact, keyword searches are frequently conducted in combination with patent classes, for example to filter out irrelevant patents from "noisy" classes.

${ }^{8}$ For a list of IPC codes and their definitions see http://www.wipo.int/ipcpub

${ }^{9}$ The CPC has been in force since January 2013. In the meantime, patent offices of China and Korea have joined the $\mathrm{CPC}$, and it is expected that other offices will do so over time. See www.cpcinfo.org

${ }^{10}$ For a list of CPC codes and their definitions see http://worldwide.espacenet.com/classification?locale=en_EP
} 


\section{Search strategies for the identification of environment-related patents}

Patents in environment-related technologies (ENV-tech) represent only a small portion of overall patenting activity. Therefore, prior to data retrieval from a patent database, a search strategy must be developed that identifies the relevant patent documents using alphanumeric symbols of the IPC or CPC systems.

Development of a search strategy requires the selection of patent classes which correspond to the target "environmental" technology field. As a first step this involves an extensive review of the trade and academic literature which relates to a specific technological field. The relevant IPC/CPC patent classes which correspond to the different fields are then identified in two alternative and complementary ways: (i) by reviewing the descriptions of the classes and (ii) by conducting test searches on each class individually to verify that they yield satisfactory outcomes in terms of inclusion of irrelevant patents. ${ }^{11}$ However, in some cases it may not be possible to identify IPC/CPC classes that alone represent the technological field of interest. In such cases it might be possible to use a combination of patent classes (socalled "co-classes") using logical operators whose intersection or negation yields the desired outcome.

When applying the search strategy, two possible types of error may arise: irrelevant patents may be included or relevant ones left out. The first error occurs if an IPC/CPC class includes patents that do not bear the desired "environmental" focus. In order to avoid this problem, a sample of patent abstracts for every IPC/CPC class considered for inclusion must be carefully examined, and classes that do not consist primarily of patents related to "environment" must be excluded. The second error - relevant inventions are left out - is less problematic. We can reasonably assume that all innovation in a given field behave in a similar way and hence our extracted datasets can be seen as, at worst, good proxies of innovative activity in the field being considered. However, overall innovative activity may be underestimated, and the totals may be less reliable than trends.

The search strategies presented in the Annex to this report draw heavily on past work of the OECD Working Party on Integrating Environmental and Economic Policies (WPIEEP) and the Working Party on Climate, Investment and Development (WPCID). Much of the groundwork for developing the strategies has benefited from collaboration with universities and research institutes (see OECD 2008 for an initial piece of work; see also OECD 2011; OECD 2012; Johnstone et al. 2010; Dechezleprêtre et al. 2015) as well as collaboration with patent examiners at the European Patent Office (see EPO/UNEP/ICTSD 2010; Haščič et al. 2010; EPO/UNEP 2013a; Haščič et al. 2012). A major advance was achieved by the introduction of the Y02 tagging scheme developed to facilitate the identification of mitigation technologies in the energy sector (Veefkind et al. 2012), and later extended to the transport and building sectors. The entire Y02 scheme has now been integrated into the CPC system. These efforts by the EPO have been of pivotal importance for patent data users not only in the business community but also in the research and policy community. This is because the Y02 scheme allows selected climate change mitigation technologies to be identified even by non-specialists. The search strategies presented in this report rely on the CPCY02 classes to the extent possible.

The efforts of the Environment Directorate to develop patent-based indicators related to selected environmental technologies (ENVTECH) complement the set of indicators developed by the OECD Directorate for Science, Technology and Innovation in the areas of information and communications technologies (ICT), biotechnology and nanotechnology (see OECD 2009 Patent Statistics Manual).

The selected IPC/CPC classes are grouped into "technological fields" that are meaningful for policy makers. The search strategies presented in this report seek to represent technologies directed at four major

\footnotetext{
${ }^{11}$ For example, using the online search engine maintained by the European Patent Office at www.espacenet.com.
} 
environmental policy objectives, including human health impacts of environmental pollution, addressing water scarcity, ecosystem health, and climate change mitigation. Consequently, several sets of search strategies are presented including those directed at (1) the traditional domains of environmental management (air and water pollution, waste disposal, etc.) as well as those directed at (2) adaptation to water scarcity, (3) addressing biodiversity threats ${ }^{12}$ and (4) mitigating climate change.

Table 3. Approximate mapping b/w environmental policy priorities and patent search strategies

\begin{tabular}{|c|c|}
\hline Environmental policy objective & Patent search strategy \\
\hline Environmental health (human health impacts) & 1. Environmental management technologies \\
\hline Water scarcity & 2. Water-related adaptation technologies \\
\hline Ecosystem health and biodiversity & 3. Biodiversity protection technologies \\
\hline Climate change & $\begin{array}{l}\text { 4. Climate change mitigation - Energy } \\
\text { 5. Climate change mitigation - Greenhouse gases } \\
\text { 6. Climate change mitigation - Transport } \\
\text { 7. Climate change mitigation - Buildings }\end{array}$ \\
\hline
\end{tabular}

In total, about 80 technological fields are covered by the ENVTECH search strategies: ${ }^{13}$

\section{SELECTED ENVIRONMENT-RELATED TECHNOLOGIES:}

1. ENVIRONMENTAL MANAGEMENT

1.1. AIR POLLUTION ABATEMENT

1.1.1. Emissions abatement from stationary sources (e.g. SOx, NOx, PM emissions from combustion plants)

1.1.2. Emissions abatement from mobile sources (e.g. NOx, CO, HC, PM emissions from motor vehicles)

1.1.3. Not elsewhere classified

1.2. WATER POLLUTION ABATEMENT

1.2.1. Water and wastewater treatment

1.2.2. Fertilizers from wastewater

1.2.3. Oil spill cleanup

1.3. WASTE MANAGEMENT

1.3.1. Solid waste collection

1.3.2. Material recycling

1.3.3. Fertilizers from waste

1.3.4. Incineration and energy recovery

1.3.5. Landfilling [n.a.]

1.3.6. Not elsewhere classified

1.4. SOIL REMEDIATION

1.5. ENVIRONMENTAL MONITORING

2. WATER-RELATED ADAPTATION TECHNOLOGIES

2.1. DEMAND-SIDE TECHNOLOGIES (water conservation)

2.1.1. Indoor water conservation (faucets, showers, sanitation, home appliances)

2.1.2. Irrigation water conservation

2.1.3. Water conservation in thermoelectric power production

2.1.4. Water distribution

2.2. SUPPLY-SIDE TECHNOLOGIES (water availability)

2.2.1. Water collection (rain, surface and ground-water)

2.2.2. Water storage

2.2.3. Desalination of sea water [n.a.]

\footnotetext{
${ }^{12}$ This is a placeholder because a corresponding search strategy is currently not yet available, although some of the technologies that are already included contribute also to improving ecosystem health (e.g. water and wastewater treatment).

${ }^{13}$ A higher level of disaggregation could be possible for some technological fields if this is of interest.
} 
3. BIODIVERSITY PROTECTION AND ECOSYSTEM HEALTH [n.a.]

4. CLIMATE CHANGE MITIGATION technologies related to ENERGY generation, transmission or distribution 4.1. RENEWABLE ENERGY GENERATION

4.1.1. Wind energy

4.1.2. Solar thermal energy

4.1.3. Solar photovoltaic $(P V)$ energy

4.1.4. Solar thermal-PV hybrids

4.1.5. Geothermal energy

4.1.6. Marine energy

4.1.7. Hydro energy (conventional, tidal, stream)

4.2. ENERGY GENERATION FROM FUELS OF NON-FOSSIL ORIGIN

4.2.1. Biofuels

4.2.2. Fuel from waste (e.g. methane)

4.3. COMBUSTION TECHNOLOGIES WITH MITIGATION POTENTIAL (e.g. using fossil fuels, biomass, waste, etc.)

4.3.1. Technologies for improved output efficiency (combined heat and power, combined cycles, etc.)

4.3.2. Technologies for improved input efficiency (efficient combustion or heat usage)

4.4. NUCLEAR ENERGY

4.4.1. Nuclear fusion reactors

4.4.2. Nuclear fission reactors

4.5. EFFICIENCY IN ELECTRICAL POWER GENERATION, TRANSMISSION OR DISTRIBUTION

4.5.1. Superconducting electric elements or equipment

4.5.2. Not elsewhere classified (incl. FACTS, APF, etc.)

4.6. ENABLING TECHNOLOGIES IN ENERGY SECTOR ${ }^{14}$

4.6.1. Energy storage

4.6.1.1. Batteries

4.6.1.2. Capacitors

4.6.1.3. Thermal storage

4.6.1.4. Pressurised fluid storage

4.6.1.5. Mechanical storage

4.6.1.6. Pumped storage

4.6.2. Hydrogen technology

4.6.3. Fuel cells

4.6.4. Smart grids in energy sector

4.7. OTHER ENERGY CONVERSION OR MANAGEMENT SYSTEMS REDUCING GHG EMISSIONS

5. CAPTURE, STORAGE, SEQUESTRATION OR DISPOSAL OF GREENHOUSE GASES

5.1. CO2 CAPTURE OR STORAGE (CCS)

5.2. CAPTURE OR DISPOSAL OF GREENHOUSE GASES OTHER THAN CARBON DIOXIDE (N2O, CH4, PFC, HFC, SF6)

6. CLIMATE CHANGE MITIGATION technologies related to TRANSPORTATION

6.1. ROAD TRANSPORT

6.1.1. Conventional vehicles (based on internal combustion engine)

6.1.2. Hybrid vehicles

6.1.3. Electric vehicles

6.1.4. Fuel efficiency-improving vehicle design (common to all road vehicles)

6.2. RAIL TRANSPORT

6.3. AIR TRANSPORT

6.4. MARITIME OR WATERWAYS TRANSPORT

6.5. ENABLING TECHNOLOGIES IN TRANSPORT

6.5.1. Electric vehicle charging

6.5.2. Application of fuel cell and hydrogen technology to transportation

7. CLIMATE CHANGE MITIGATION technologies related to BUILDINGS

7.1. INTEGRATION OF RENEWABLE ENERGY SOURCES IN BUILDINGS

7.2. ENERGY EFFICIENCY IN BUILDINGS

\footnotetext{
${ }^{14}$ Technologies with potential or indirect contribution to GHG emissions mitigation
} 


\author{
7.2.1. Lighting \\ 7.2.2. Heating, ventilation or air conditioning [HVAC] \\ 7.2.3. Home appliances \\ 7.2.4. Elevators, escalators and moving walkways \\ 7.2.5. Information and communication technologies [ICT] \\ 7.2.6. End-user side \\ 7.3. ARCHITECTURAL OR CONSTRUCTIONAL ELEMENTS IMPROVING THE THERMAL \\ PERFORMANCE OF BUILDINGS \\ 7.4. ENABLING TECHNOLOGIES IN BUILDINGS
}

Obviously, the patents that can be identified using these search strategies will be only a sub-set of the "population" of patented technologies with a potential to contribute to reducing negative environmental impacts. As a ballpark figure, the selected environmental technologies as currently defined represent approximately $5-10 \%$ of all patented inventions globally, and this figure would change depending on the "breadth" of the definition adopted. ${ }^{15}$

It should be noted that an aggregation of environment-related technological fields will necessarily include innovations directed at sometimes conflicting environmental policy objectives. Due to their very nature, it is impossible to identify technologies with unequivocally positive environmental benefit; this is because the benefit of "environment-related technologies" will ultimately depend on how they are used and applied in practice. Unlike for biotech, nanotech or ICT fields that can be defined using an "objective" criterion, there is no such objective criterion for envtech. Indeed, "greenness" is a somewhat elusive concept and, consequently, it might sometimes be difficult to interpret such statistics for policy purposes.

\title{
2.3. Construction of patent statistics using the PATSTAT database
}

\section{Patent database}

In the 2000s, the OECD Directorate for Science, Technology and Innovation, jointly with other members of the OECD Patent Statistics Taskforce, ${ }^{16}$ worked on the development of a patent database that would be suitable for statistical analysis. These efforts resulted in launching the Worldwide Patent Statistical Database (PATSTAT). The European Patent Office (EPO) has taken over responsibility for development and management of the database. The PATSTAT Database is drawn directly from the EPO's master database (Rollinson and Lingua 2007). It has been developed specifically for use by (inter)governmental organisations and academic institutions, and optimised for the statistical analysis of patent data. It has become a primary source of patent data information for statisticians, academics, and policy advisors (Rollinson and Heijnar 2006).

The PATSTAT Database has a world-wide coverage containing data from over 90 patent offices, spanning a time period stretching back to 1880 for some countries. This covers patent documents from all major patent offices in the world including regional patent offices and international patent applications filed under the Patent Cooperation Treaty (PCT). Currently, almost 80 million patent documents are included (EPO 2014). The database is updated on a regular basis biannually. Patent documents are categorised using the International Patent Classification (IPC) and the Cooperative Patent Classification (CPC) systems. In

${ }^{15}$ During over two decades (1980-2005) the proportion was rather stable at around 5\%. Since 2005 it has been increasing to a current level of about $10 \%$.

${ }^{16}$ Other Taskforce members include the European Patent Office (EPO), the Japan Patent Office (JPO), the United States Patent and Trademark Office (USPTO), the World Intellectual Property Organisation (WIPO), the US National Science Foundation (NSF), Eurostat, and the European Commission Directorate-General for Research. 
addition to the basic bibliometric and legal data, the database also includes patent descriptions (abstracts), applicant and inventor names, as well as citation data. The PATSTAT Database is thus an ideal source of information for the purposes of the production of patent-based indicators.

\section{Patent statistics}

PATSTAT contains information covering the entire "life cycle" of a patent - starting with the first patent application ("priority" application), its examination, and possibly the granting of a patent (information on patent licensing is not included). In addition, a number of attributes are recorded, including the names and addresses of the inventor (the researcher) and the applicant (often the researcher herself or her employer). This wealth of information allows various types of patent statistics to be calculated:

- The counts of priority applications by the country of inventor's residence is a measure of inventive activity, and can be used to study trends in technology development. Since data from multiple patent offices are pooled together, excluding duplicates ensures that inventions are not double-counted. In addition, these statistics can be further distinguished according to the size of the international patent family (i.e. the number of patent authorities where patent applications were filed to protect the same invention). The advantage of counts based on all inventions (family size $>=1$ ) is that the resulting statistics are truly world-wide as the entire stock of patent priorities is considered.

At the same time, counting only those patent applications that have been "claimed" as priority" provides the additional benefit that low-value inventions that typically seek protection only at a single patent office (singletons) may be excluded. It has been argued that a statistic based on the "claimed priorities" (family size $>=2$ ) is the most suitable for the purpose of international comparisons because only the "high-value" priority applications are counted without placing an excessive constraint on 'narrow' technological fields (which is often the case when using e.g. the triadic patent family indicator). The reason that claimed priorities can be viewed as representing inventions of higher value is that patenting is costly (e.g. translation and maintenance fees). As such, a firm will only protect its intellectual property in more than one jurisdiction if it is justified by the potential commercial value. ${ }^{18}$ Moreover, by excluding priority applications which have never been claimed abroad (one-member families, or singletons) this approach may help contain concerns over strategic patenting. ${ }^{19}$

- While most patent applications include inventors from the same country, some inventions are the outcome of collaboration by inventors from multiple countries. This information allows counts of

17 The Paris Convention for the Protection of Industrial Property (1883) stipulates that patent applications abroad must be filed within one year of the date when the initial application was filed (referred to as "priority date"). If the inventor does file abroad within one year, the inventor will have priority over any similar patent applications received in those countries since the priority date. (The more recent Patent Co-operation Treaty allows additional 18 months to make any duplicate filings in signatory countries.)

${ }^{18}$ For empirical evidence supporting this argument see Guellec and van Pottelsberghe (2000) and Harhoff et al. (2003). Indeed, the use of an indicator which excludes the "one-member" patent families - that is, an indicator based on "claimed priorities" - was first advocated by Faust and Schedl (1983) and Faust (1990). Among other things, the benefit put forward by Faust (1990) was that the counts will exclude the large number of exclusively domestic Japanese patent applications with usually only one claim.

${ }^{19}$ Claimed priorities (or PF2) represent about 30-40\% of the stock of inventions, the remainder of inventions are only protected at a single patent office (singletons). It must be noted that there is variation in these proportions across patent offices. 
"co-inventions" to be constructed and used to study international collaboration in technology development.

- In addition, it is possible to find information about the various patent offices where patent protection for a given invention has been sought. While the large majority of inventions are only patented at a single patent office (often the 'home' office of the inventor or the applicant), some inventions seek protection in multiple patent jurisdictions depending on the commercial strategy and market expectations of the applicant. This allows counts of patent applications by patent office to be constructed which is a measure of patenting activity and can be used to study trends in markets for innovations.

- PATSTAT also includes data on "patent citations" that can be used to measure international knowledge flows (see e.g., Guellec and van Pottelsberghe de la Potterie 2000; Dechezleprêtre et al. 2015).

Finally, it is important to emphasise that patenting processes and patent data are complex and their use and interpretation require caution, for example to avoid double-counting of inventions and misinterpreting data. In addition, patent databases (as any other sources of data) have their own idiosyncrasies but in many cases they can be mitigated. The companion paper (Haščič et al. 2015) provides a discussion of the methodology of how more accurate patent statistics can be constructed. 


\section{GREEN GROWTH INDICATORS BASED ON PATENT DATA}

\subsection{Indicator of technology development (inventive activity)}

An indicator of inventive activity is constructed as a count of priority patent applications, disaggregated by:

- Technological field - based on patent search strategies shown in the Annex;

- Invention year - based on the priority date ${ }^{20}$;

- Inventor country - based on country of residence of the inventor(s), as fractional count ${ }^{21}$;

- International patent family size - including the priority filing and its equivalents deposited at other patent offices, distinguishing between:

$\circ$ All inventions world-wide (family size $>=1$, using the PF1 statistic)

- High-value inventions (family size $>=2,3$ or 4 , using PF2, PF3 or PF4 statistics) ${ }^{22}$.

Figure 1 presents the counts for the three broad groups of technologies, aggregated across all countries worldwide. It shows that innovations in climate change mitigation increased 6-fold and those in waterrelated adaptation almost 4-fold over the 20-year period, 1990-2010, but that innovations in environmental management increased only about as much as did innovation overall (the dotted line).

Figure 1. Inventive activity in selected environment-related technologies

(High-value inventions (PF2), 3-year moving average, world total, indexed on 1990=100)

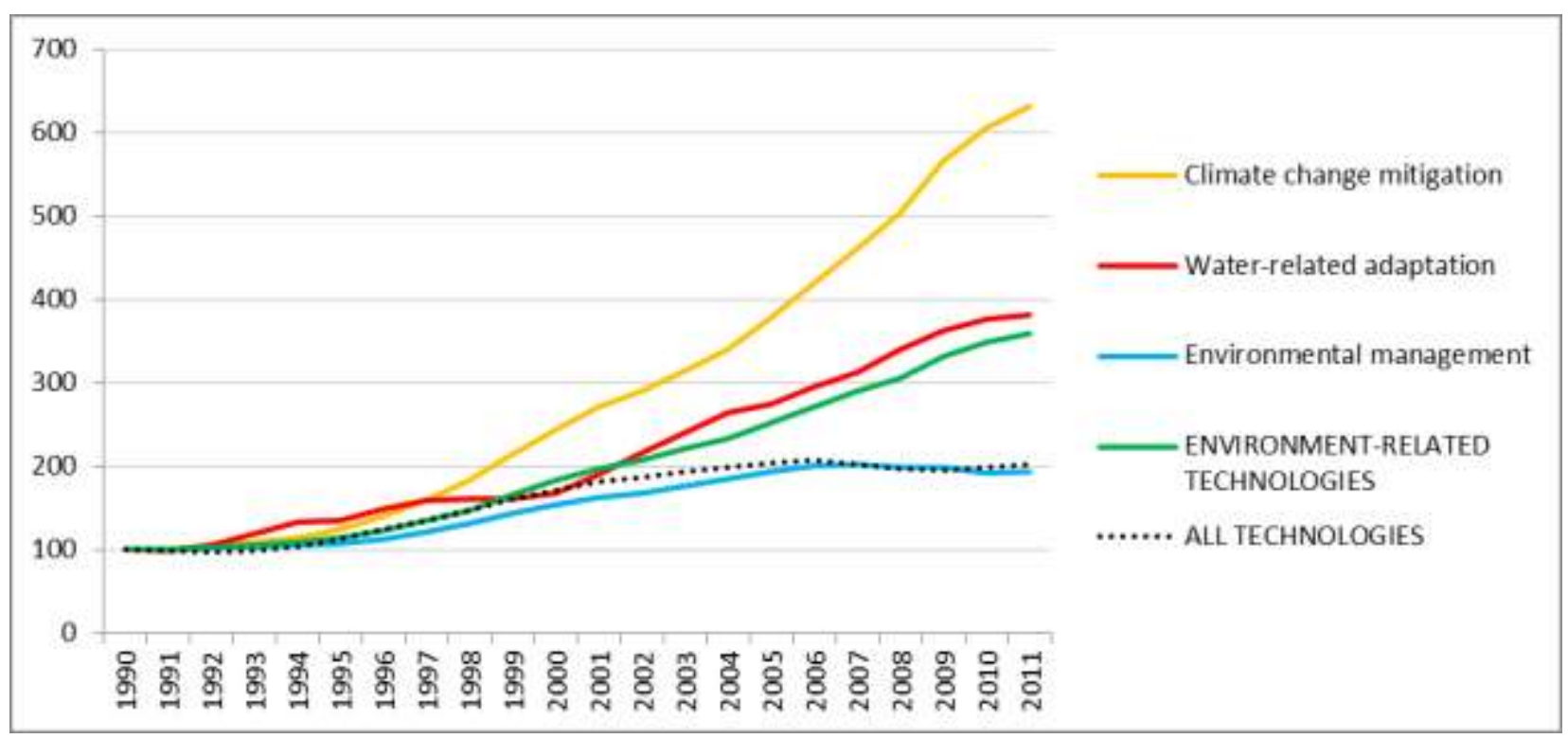

${ }^{20}$ The "priority date" is the filing date of the first application world-wide (within a given simple patent family) and is considered to be a good proxy for the date of invention.

${ }^{21}$ Generating the counts as "fractional" means that if inventors from two (three, or more) different countries are involved, only a fraction of $0.5(0.33$, etc.) will be counted for a given patent application.

${ }^{22}$ See the companion paper (Haščič et al. 2015) for a discussion of the statistics. 
Figure 2 presents a similar graphic but at a more disaggregated level. Interestingly, all of the fastestgrowing technologies are climate change-related - in particular wind energy, electric vehicle charging, and electric and hybrid road vehicle technologies. Several renewable energy generation technologies and those related to climate change mitigation in buildings have also been growing fast, and notably faster than innovations overall (shown by the dotted line in panel A of Figure 2). On the other hand, environmentrelated technologies that have been growing at the slowest pace include waste management, water pollution abatement, nuclear energy and rail transport, indicating a certain degree of maturity of these fields. The rate of innovation in soil remediation technologies has actually declined (panel B of Figure 2).

Figure 2. Inventive activity: the fastest (panel A) and slowest growing technologies (panel B)
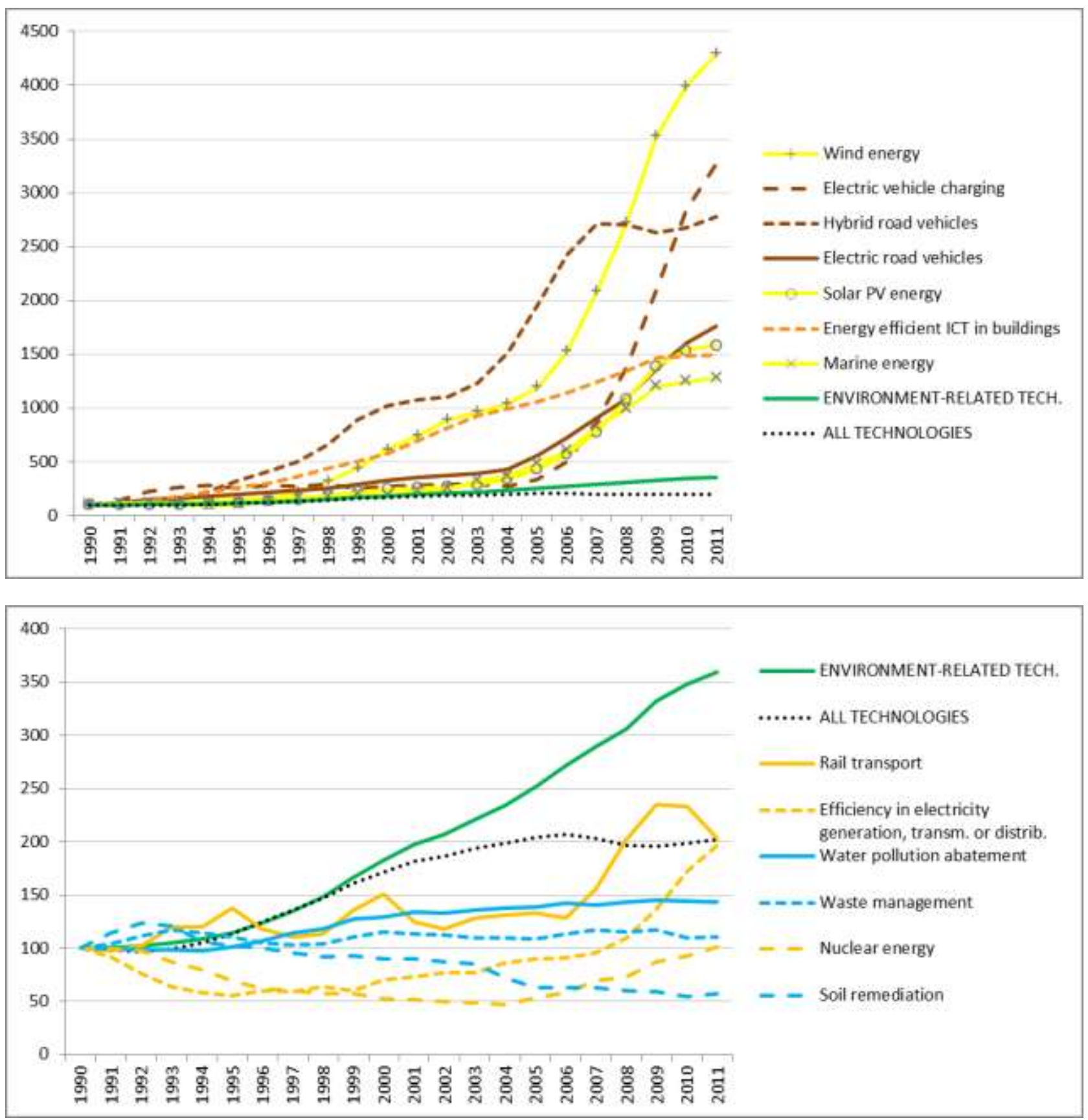
ENV/WKP(2015)10

Table 4. Number of inventions by OECD and G20 countries

(Sum over 2000-2011, all inventions (PF1))

\begin{tabular}{|c|c|c|c|c|}
\hline Inventor country & $\begin{array}{r}\text { ENVIRONMENTAL } \\
\text { MANAGEMENT }\end{array}$ & $\begin{array}{r}\text { WATER-RELATED } \\
\text { ADAPTATION }\end{array}$ & $\begin{array}{r}\text { CLIMATE CHANGE } \\
\text { MITIGATION }\end{array}$ & $\begin{array}{r}\text { ALL TECHNOLOGIES } \\
\text { (PATSTAT total) }\end{array}$ \\
\hline United States & 55821 & 6610 & 118014 & 1953162 \\
\hline European Union (EU28) & 76781 & 5923 & 138402 & 1533704 \\
\hline Korea & 44654 & 2985 & 84591 & 1232567 \\
\hline Japan & 43080 & 1401 & 86017 & 1000279 \\
\hline Germany & 39379 & 2520 & 68455 & 678701 \\
\hline China & 23119 & 1358 & 42179 & 675325 \\
\hline Russian Fed. & 6726 & 652 & 11391 & 223568 \\
\hline France & 8969 & 837 & 16684 & 183535 \\
\hline United Kingdom & 6431 & 1083 & 13279 & 177851 \\
\hline Canada & 5004 & 611 & 9966 & 126272 \\
\hline Italy & 3695 & 250 & 6181 & 83517 \\
\hline Netherlands & 2176 & 189 & 4767 & 76474 \\
\hline Switzerland & 1488 & 388 & 3495 & 58888 \\
\hline Sweden & 2476 & 135 & 3938 & 55586 \\
\hline Israel & 740 & 246 & 2465 & 47444 \\
\hline India & 1182 & 204 & 2803 & 46266 \\
\hline Spain & 1791 & 196 & 4299 & 44093 \\
\hline Australia & 1856 & 380 & 3299 & 41925 \\
\hline Finland & 1503 & 54 & 2338 & 39468 \\
\hline Austria & 2303 & 114 & 3787 & 37539 \\
\hline Poland & 2505 & 96 & 3042 & 34214 \\
\hline Belgium & 1120 & 165 & 1961 & 29010 \\
\hline Denmark & 1138 & 81 & 3644 & 27677 \\
\hline Norway & 715 & 103 & 1443 & 16694 \\
\hline Turkey & 262 & 37 & 632 & 12751 \\
\hline Ireland & 288 & 40 & 556 & 11107 \\
\hline Czech Rep. & 762 & 31 & 1077 & 10295 \\
\hline Mexico & 554 & 58 & 846 & 9989 \\
\hline Brazil & 480 & 53 & 784 & 9312 \\
\hline Hungary & 551 & 24 & 850 & 8957 \\
\hline New Zealand & 263 & 23 & 507 & 7557 \\
\hline South Africa & 329 & 33 & 622 & 6897 \\
\hline Slovenia & 128 & 8 & 233 & 4632 \\
\hline Greece & 242 & 27 & 555 & 4514 \\
\hline Portugal & 142 & 10 & 381 & 3735 \\
\hline Argentina & 83 & 17 & 195 & 3027 \\
\hline Slovak Rep. & 199 & 9 & 316 & 2824 \\
\hline Saudi Arabia & 210 & 19 & 254 & 1900 \\
\hline Colombia & 115 & 15 & 146 & 1826 \\
\hline Luxembourg & 150 & 3 & 204 & 1674 \\
\hline Chile & 135 & 9 & 157 & 1295 \\
\hline Latvia & 60 & 1 & 131 & 1203 \\
\hline Lithuania & 89 & 1 & 143 & 1187 \\
\hline Iceland & 15 & 1 & 36 & 910 \\
\hline Estonia & 52 & 1 & 98 & 890 \\
\hline Indonesia & 22 & 4 & 55 & 769 \\
\hline Costa Rica & 16 & 1 & 21 & 430 \\
\hline OECD & 230587 & 18726 & 448112 & 6026029 \\
\hline BRIICS & 31858 & 2304 & 57834 & 962138 \\
\hline World & 270562 & 21637 & 527317 & 7411755 \\
\hline
\end{tabular}


Table 4 presents the indicator for a sample of selected countries. It shows that countries that are major inventors in general (all technologies) are not necessarily equally active in environment-related technologies. This information is complemented by Table 5 showing that country ranking varies somewhat depending the "value" of inventions (measured by patent family size).

Table 5. Most important inventor countries globally in environment related technologies

(2009-2011, all inventions (PF1) and high-value inventions (PF2))

\begin{tabular}{clcc}
\hline Rank & Country & \% of world's inventions & $\begin{array}{c}\text { \% of world's high-value } \\
\text { inventions }\end{array}$ \\
\hline 1 & United States & $21.1 \%$ & $16.5 \%(3)$ \\
2 & Korea & $21.0 \%$ & $9.2 \%(4)$ \\
3 & Japan & $15.5 \%$ & $24.8 \%(1)$ \\
4 & Germany & $12.6 \%$ & $17.9 \%(2)$ \\
5 & China & $3.9 \%$ & $3.8 \%(6)$ \\
6 & France & $3.8 \%$ & $5.6 \%(5)$ \\
7 & Chinese Taipei & $3.2 \%$ & $3.4 \%(8)$ \\
8 & United Kingdom & $2.4 \%$ & $3.6 \%(7)$ \\
9 & Russian Federation & $2.0 \%$ & $0.3 \%(22)$ \\
10 & Canada & $1.6 \%$ & $1.3 \%(10)$ \\
\hline & EU28 & $26.8 \%$ & $36.9 \%$ \\
& OECD & $88.2 \%$ & $90.6 \%$ \\
& BRIICS & $6.9 \%$ & $5.1 \%$ \\
\hline
\end{tabular}

Assessment of inventive activity in environmental technologies can be facilitated if it is placed in context, that is, if it is compared with inventive activity overall (in all technologies). Moreover, it might be useful to contrast a country's performance with those of other countries. To allow such bi-dimensional assessment of the extent to which countries "specialise" in a given technological field, we calculate the "relative technological advantage" (RTA) of country $i$ in technology $k$ as country $i$ 's share of $k$-priorities worldwide compared to its share of all priorities. (RTA $>1$ means that a country is more active in a selected field than it is in all technologies overall.) Table 6 shows that, for example, Germany tends to specialise in air pollution abatement technologies, Poland, Slovakia and the Czech Republic specialise in waste management technologies, Denmark in renewable energy, and Japan in electric and hybrid vehicles. 
Table 6. Specialisation in environment-related technologies

(Relative technological advantage (RTA), 2000-2011, high-value inventions (PF2))

\begin{tabular}{|c|c|c|c|c|c|c|c|c|c|}
\hline $\begin{array}{l}\text { Inventor } \\
\text { country }\end{array}$ & $\begin{array}{r}\text { Air } \\
\text { pollution }\end{array}$ & $\begin{array}{r}\text { Water } \\
\text { pollution }\end{array}$ & $\begin{array}{l}\text { Waste } \\
\text { mgmt. }\end{array}$ & $\begin{array}{c}\text { Water } \\
\text { conserv. }\end{array}$ & $\begin{array}{r}\text { Renewable } \\
\text { energy }\end{array}$ & $\begin{array}{r}\text { Electric/ } \\
\text { hybrid } \\
\text { vehicles }\end{array}$ & $\begin{array}{l}\text { Energy- } \\
\text { efficient } \\
\text { lighting }\end{array}$ & $\begin{array}{r}\text { Energy- } \\
\text { efficient } \\
\text { HVAC }\end{array}$ & $\begin{array}{l}\text { All tech- } \\
\text { nologies }\end{array}$ \\
\hline Australia & 0.4 & 2.8 & 2.1 & 2.0 & 1.2 & 0.3 & 1.1 & 1.2 & 1 \\
\hline Austria & 1.4 & 1.6 & 2.6 & 0.8 & 1.4 & 0.8 & 1.7 & 1.6 & 1 \\
\hline Belgium & 0.8 & 1.5 & 2.0 & 1.3 & 1.2 & 0.0 & 0.4 & 1.5 & 1 \\
\hline Canada & 0.5 & 2.1 & 1.9 & 1.7 & 0.9 & 0.3 & 0.8 & 0.8 & 1 \\
\hline Czech Rep. & 0.9 & 2.8 & 6.8 & 0.4 & 1.0 & 0.6 & 0.6 & 2.7 & 1 \\
\hline Denmark & 0.8 & 2.0 & 1.3 & 1.0 & 8.4 & 0.1 & 0.2 & 2.7 & 1 \\
\hline Finland & 0.7 & 1.9 & 2.8 & 0.5 & 0.6 & 0.2 & 0.5 & 1.2 & 1 \\
\hline France & 1.0 & 1.2 & 1.3 & 1.3 & 0.9 & 0.8 & 0.3 & 1.3 & 1 \\
\hline Germany & 1.7 & 1.1 & 1.0 & 1.1 & 1.4 & 1.1 & 0.7 & 1.1 & 1 \\
\hline Greece & 1.1 & 2.5 & 3.0 & 2.1 & 3.6 & 0.7 & 0.4 & 0.5 & 1 \\
\hline Hungary & 0.5 & 2.6 & 3.9 & 1.0 & 0.8 & 0.1 & 7.3 & 0.6 & 1 \\
\hline Ireland & 0.3 & 1.0 & 1.7 & 0.4 & 1.7 & 0.1 & 0.6 & 1.0 & 1 \\
\hline Israel & 0.1 & 1.2 & 0.8 & 1.9 & 1.0 & 0.5 & 0.7 & 0.4 & 1 \\
\hline Italy & 0.8 & 1.2 & 2.1 & 0.9 & 1.3 & 0.4 & 0.6 & 1.9 & 1 \\
\hline Japan & 1.3 & 0.7 & 0.7 & 0.4 & 0.6 & 1.8 & 0.9 & 0.9 & 1 \\
\hline Korea & 0.4 & 0.8 & 0.7 & 0.5 & 1.0 & 0.6 & 1.6 & 1.5 & 1 \\
\hline Mexico & 0.8 & 2.3 & 4.1 & 1.6 & 1.1 & 0.1 & 2.2 & 0.5 & 1 \\
\hline Netherlands & 0.5 & 1.8 & 1.8 & 0.7 & 1.5 & 0.3 & 1.2 & 2.3 & 1 \\
\hline New Zealand & 0.2 & 1.9 & 2.8 & 0.9 & 1.4 & 0.5 & 0.6 & 1.3 & 1 \\
\hline Norway & 0.8 & 3.1 & 1.9 & 1.9 & 3.0 & 0.1 & 0.1 & 1.1 & 1 \\
\hline Poland & 0.8 & 2.9 & 7.5 & 0.9 & 1.6 & 0.1 & 0.7 & 3.2 & 1 \\
\hline Portugal & 0.6 & 1.5 & 2.6 & 0.8 & 3.8 & 0.2 & & 3.4 & 1 \\
\hline Slovak Rep. & 0.5 & 2.2 & 7.0 & 0.9 & 2.8 & 0.1 & 1.3 & 1.0 & 1 \\
\hline Slovenia & 0.2 & 0.3 & 0.6 & & 0.6 & 0.2 & 0.2 & 2.9 & 1 \\
\hline Spain & 0.4 & 1.5 & 2.4 & 1.0 & 3.6 & 0.3 & 0.1 & 1.2 & 1 \\
\hline Sweden & 1.2 & 1.3 & 1.0 & 0.8 & 0.7 & 0.7 & 0.2 & 0.8 & 1 \\
\hline Switzerland & 0.4 & 1.2 & 1.2 & 2.3 & 1.1 & 0.2 & 0.8 & 1.2 & 1 \\
\hline Turkey & 0.7 & 0.6 & 0.7 & 1.8 & 1.4 & 0.2 & 0.3 & 2.3 & 1 \\
\hline UK & 0.7 & 1.4 & 1.3 & 2.2 & 1.2 & 0.3 & 0.6 & 0.9 & 1 \\
\hline USA & 1.0 & 1.0 & 0.8 & 1.8 & 0.8 & 0.9 & 0.8 & 0.6 & 1 \\
\hline Brazil & 0.6 & 2.5 & 3.0 & 1.3 & 0.9 & 0.2 & 0.3 & 0.6 & 1 \\
\hline China & 0.3 & 0.9 & 0.8 & 0.5 & 1.0 & 0.5 & 2.5 & 0.8 & 1 \\
\hline India & 0.6 & 0.9 & 0.8 & 3.6 & 1.2 & 0.4 & 0.9 & 0.4 & 1 \\
\hline Russian Fed. & 0.6 & 2.5 & 2.5 & 2.0 & 1.2 & 0.1 & 1.2 & 0.5 & 1 \\
\hline South Africa & 0.4 & 2.3 & 1.4 & & 1.2 & 0.2 & 2.1 & 1.2 & 1 \\
\hline BRIICS & 0.4 & 1.1 & 1.0 & 1.0 & 1.0 & 0.4 & 2.1 & 0.7 & 1 \\
\hline World & 1 & 1 & 1 & 1 & 1 & 1 & 1 & 1 & 1 \\
\hline
\end{tabular}

Note: Top three performers in each field are highlighted. The table shows only countries with a minimum 200 inventions in ENVTECH during the 2000-2011 period. This is because generally low levels of inventive activity might lead to spuriously high RTA scores.

Table 7 presents three alternative metrics to assess inventive activity of countries: (i) a simple count of relevant inventions, (ii) as percent of all technologies, and (iii) as RTA. These three sets of indexes show the extent to which a country innovates in 'environmental' technologies, whether it innovates increasingly in 'environmental', and how this compares with other countries. For example, in OECD countries (as a group) innovation in 'environmental' technologies increased by $70 \%$ between 2000 and 2011, and by $69 \%$ 
as a proportion of overall innovation, indicating that 'environmental' innovation increased at about the same rate as the innovation in general. However, compared to what happened in other countries, the increase - only $4 \%$ - appears relatively modest, and is in line with the trends elsewhere in the world. The situation is very different in BRIICS countries that have seen their innovations in 'environmental' technologies skyrocket by $497 \%$. This however appears to be a reflection of a more general phenomenon because the increase is only $45 \%$ in terms of the share on all innovations. Moreover, compared to developments in other countries, their innovation performance actually decreased! The countries that truly strengthened their relative technological advantage in 'environmental' technologies were Denmark, Finland and India.

Table 7. Assessment of inventive activity using alternative metrics (2011)

(Environment-related technologies, indexed on $2000=100$, high-value inventions (PF2))

\begin{tabular}{|c|c|c|c|c|c|c|c|}
\hline \multirow[b]{3}{*}{ Inventor country } & \multirow{3}{*}{$\begin{array}{l}\text { Index based on } \\
\text { simple count }\end{array}$} & \multirow{3}{*}{$\begin{array}{l}\text { Index based on } \\
\% \text { of all tech. }\end{array}$} & \multirow{3}{*}{$\begin{array}{l}\text { Index based } \\
\text { on RTA }\end{array}$} & \multicolumn{4}{|c|}{ Count of inventions } \\
\hline & & & & \multicolumn{2}{|c|}{ Environment-related tech. } & \multicolumn{2}{|c|}{ All technologies } \\
\hline & & & & 2000 & 2011 & 2000 & 2011 \\
\hline Denmark & 519 & 453 & 280 & 39 & 204 & 560 & 641 \\
\hline Finland & 227 & 296 & 183 & 74 & 167 & 1905 & 1460 \\
\hline India & 859 & 295 & 183 & 18 & 152 & 390 & 1136 \\
\hline Spain & 283 & 249 & 154 & 58 & 164 & 1057 & 1201 \\
\hline France & 235 & 234 & 145 & 469 & 1100 & 8561 & 8587 \\
\hline Israel & 178 & 228 & 141 & 42 & 74 & 1219 & 951 \\
\hline Switzerland & 217 & 227 & 141 & 74 & 161 & 1926 & 1842 \\
\hline United Kingdom & 154 & 226 & 140 & 429 & 661 & 8589 & 5858 \\
\hline China & 1276 & 223 & 138 & 65 & 827 & 2032 & 11598 \\
\hline Italy & 224 & 219 & 136 & 206 & 460 & 4534 & 4631 \\
\hline United States & 163 & 191 & 118 & 1882 & 3065 & 31938 & 27210 \\
\hline Korea & 493 & 188 & 116 & 356 & 1752 & 6668 & 17463 \\
\hline Ireland & 191 & 184 & 114 & 12 & 23 & 264 & 273 \\
\hline OECD & 170 & 169 & 104 & 10142 & 17230 & 152652 & 153694 \\
\hline Sweden & 91 & 164 & 102 & 169 & 155 & 3155 & 1754 \\
\hline Germany & 157 & 159 & 98 & 2163 & 3394 & 25078 & 24816 \\
\hline Norway & 125 & 156 & 96 & 51 & 64 & 691 & 553 \\
\hline Netherlands & 96 & 151 & 94 & 141 & 135 & 2202 & 1398 \\
\hline BRIICS & 597 & 145 & 90 & 180 & 1074 & 3372 & 13860 \\
\hline Japan & 145 & 141 & 87 & 3348 & 4856 & 46110 & 47367 \\
\hline Austria & 164 & 140 & 87 & 138 & 226 & 1526 & 1781 \\
\hline Australia & 29 & 132 & 82 & 138 & 41 & 1777 & 395 \\
\hline Canada & 121 & 121 & 75 & 206 & 250 & 2659 & 2657 \\
\hline Czech Republic & 250 & 116 & 72 & 12 & 30 & 121 & 260 \\
\hline Belgium & 100 & 111 & 69 & 68 & 68 & 1072 & 961 \\
\hline Poland & 379 & 110 & 68 & 11 & 42 & 108 & 370 \\
\hline Luxembourg & 72 & 73 & 45 & 13 & 9 & 91 & 90 \\
\hline Russian Fed. & 68 & 60 & 37 & 83 & 56 & 612 & 684 \\
\hline
\end{tabular}

Note: Only countries with a minimum 10 inventions in 2000 are shown. 


\subsection{Indicator of international collaboration in technology development (co-invention)}

An indicator of co-inventive activity is constructed as a count of priority patent applications with inventors from at least two different countries, disaggregated by:

- Technological field - based on a patent search strategies shown in the Annex;

- Invention year - based on the priority date;

- Inventor country - based on the country of residence of the inventors, and including:

- bilateral relationships between pairs of co-inventor countries;

$\circ$ counts of co-inventions with a foreign partner.

Table 8 presents the indicator in terms of the bilateral relationships - the country pairs - whose inventors collaborated most often in technology development. Not surprisingly inventors from large countries rank highest, including the USA, Germany and China. Interestingly, India also features rather high which is somewhat unexpected for a mid-size inventor country and it shows that its researchers tend to collaborate internationally more frequently than other countries with similar innovation performance. The absence of Japan is noteworthy suggesting that its inventive activity is primarily domestically oriented.

Table 8. Top co-inventing country pairs in 2011

(Number of co-inventions)

\begin{tabular}{|c|c|c|c|c|c|c|c|}
\hline \multirow{2}{*}{ Rank } & \multirow{2}{*}{$\begin{array}{c}\text { ENVIRONMENTAL } \\
\text { MANAGEMENT }\end{array}$} & \multirow{2}{*}{$\begin{array}{l}\text { WATER-RELATED } \\
\text { ADAPTATION }\end{array}$} & \multicolumn{4}{|c|}{ CLIMATE CHANGE MITIGATION TECHNOLOGIES } & \multirow{2}{*}{$\begin{array}{c}\text { ALL } \\
\text { TECHNOLOGIES }\end{array}$} \\
\hline & & & ENERGY & GHG & TRANSPORT & BUILDINGS & \\
\hline 1 & USA-CHN & USA-IND & USA-CHN & USA-IND & USA-IND & USA-CHN & USA-CHN \\
\hline 2 & USA-DEU & USA-DEU & USA-IND & USA-FRA,DEU & USA-DEU & USA-IND & USA-IND \\
\hline 3 & USA-IND & USA-FRA & USA-DEU & USA-CHN & FRA-DEU & USA-CAN & USA-CAN \\
\hline 4 & USA-GBR & $\begin{array}{c}\text { DEU-CHE } \\
\text { and USA-GBR }\end{array}$ & USA-CAN & $\begin{array}{c}\text { DEU-CHE,BEL,AUT } \\
\text { and FRA-CHN } \\
\text { and USA-GBR }\end{array}$ & NLD-DEU & USA-KOR & TWN-CHN \\
\hline 5 & USA-CAN & $\begin{array}{c}\text { FRA-DEU and } \\
\text { USA-CHN,CHE,CAN }\end{array}$ & USA-GBR & $\begin{array}{c}\text { FRA-DEU } \\
\text { and NLD-DEU,BEL }\end{array}$ & USA-CAN & USA-ISR & USA-GBR \\
\hline
\end{tabular}

Encouraging international collaboration in technology development is particularly important in areas that have public good characteristics, such climate change mitigation. Table 9 shows the co-invention rates that is, the percentage of inventions that have been developed with a foreign inventor. Not surprisingly, inventors from small countries tend to collaborate frequently but several "emerging" inventor countries rank high as well, such as India. On the other hand, Korea and Japan frequently rank among those whose inventors collaborate the least. 
ENV/WKP(2015)10

Table 9. Top ten and bottom ten co-invention rates in climate change mitigation technologies

(Share of co-inventions with foreign partner, 2011)

\begin{tabular}{lllc}
\hline & \multicolumn{2}{c}{ Co-invention rate (\%) } \\
Inventor country & \multicolumn{1}{c}{$\begin{array}{c}\text { Climate change } \\
\text { mitigation }\end{array}$} & All technologies \\
\hline Luxembourg & Energy & 97 & 94 \\
Australia & Energy & 94 & 66 \\
New Zealand & Energy & 91 & 71 \\
India & Transport & 90 & 77 \\
Ireland & Buildings & 90 & 67 \\
India & Energy & 86 & 77 \\
Australia & Buildings & 86 & 66 \\
Switzerland & Transport & 81 & 58 \\
India & Buildings & 75 & 77 \\
Denmark & Buildings & 74 & 45 \\
..other & & & \\
France & Transport & 11 & 23 \\
Romania & Energy & 10 & 17 \\
Chinese Taipei & Energy & 9 & 16 \\
Korea & Buildings & 7 & 5 \\
Korea & GHG & 7 & 5 \\
Korea & Energy & 5 & 5 \\
Korea & Transport & 4 & 5 \\
Japan & Transport & 4 & 23 \\
Poland & Buildings & 4 & 12 \\
Romania & Transport & 0 & 17 \\
\hline
\end{tabular}

Note: The table shows only countries with a minimum 10 co-inventions in total (in all technologies). 


\subsection{Indicator of technology diffusion (market protection)}

As a measure technology diffusion an indicator constructed as a count of inventions (patent families) that have sought patent protection in a given jurisdiction (as evidenced by registered patent applications, not necessarily by granted patents). The indicator is disaggregated by:

- Technological field - based on a patent search strategies shown in the Annex;

- Application authority (patent office) - including both national and regional patent authorities;

- Application year - based on patent application filing date;

- Coverage - based on database bibliographic data, distinguishing between:

- Full dataset (no restriction on coverage) including all counts, even if based on incomplete information;

- Conservative coverage including only those years and offices for whom near-complete $(\geq 90 \%)$ data is available (for more details, see Haščič et al. 2015).

Patenting is costly and an applicant will file a patent application only if there is a potential market for the invention (e.g. sales or exports of products, investments, or royalties from licensing). A patent provides protection only in a particular jurisdiction and innovators need to file multiple patents if they seek to have their innovations protected in multiple markets.

Table 10 presents the indicator for material recycling and the broader group of waste management technologies with patent applications filed at patent offices with jurisdiction in OECD and G20 countries. The extraordinarily high figures for China are likely a reflection of both optimistic market expectations of patent applicants as well as low patentability standards and narrow patent 'breath' required by the Chinese patent office. ${ }^{23}$ In Europe, the regional European Patent Office (EPO) is the most important patent authority, and increasingly so. On the other hand, the number of patents filed in countries such as Colombia or Costa Rica remains very low. For some countries, such as Chile, data availability is insufficient for some years; this is the reason why, under 'conservative' coverage, Chile is not included in Table 10.

Indeed, while over $15 \%$ of the world's stock of environment-related inventions seek protection in China, Japan, the United States, Korea and European markets, less than 1\% of world's environment-related inventions are protected in Brazil, Argentina, Morocco, Colombia, Peru, Egypt, and many other countries of Africa, Latin America and Asia (Table 11).

It is interesting to contrast the importance of a country's market (Table 11) with the importance of its inventors (Table 5). Table 12 presents such comparison for selected patent offices. It shows that countries that rank high as important markets for new technologies do not necessarily rank as high in terms of the inventive output of its economies. For example, China ranks $1^{\text {st }}$ in the number of registered ENVTECH patent applications but ranks $5^{\text {th }}$ in terms of the number of inventions; Australia ranks $11^{\text {th }}$ in terms of ENVTECH patent applications but only $27^{\text {th }}$ in terms of inventions.

\footnotetext{
${ }^{23}$ This is in line with the literature on optimal intellectual property rights (IPR) protection that suggests relatively low levels of IPR protection for developing countries. From the measurement perspective, the differences in patent 'breath' are one of the reasons why this paper promotes the use of the indicator of inventive activity based on high-value inventions (e.g. the PF2 statistic).
} 
Table 10. Diffusion of waste management technologies, 2011

(Number of inventions for which patent protection is sought, 'conservative' coverage)

\begin{tabular}{|c|c|c|c|}
\hline Patent office & $\begin{array}{l}\text { Material } \\
\text { recycling }\end{array}$ & $\begin{array}{r}\text { WASTE } \\
\text { MANAGEMENT }\end{array}$ & $\begin{array}{r}\text { ALL } \\
\text { TECHNOLOGIES } \\
\end{array}$ \\
\hline China & 1859 & 3950 & 436386 \\
\hline Japan & 636 & 1644 & 263012 \\
\hline United States & 444 & 1017 & 240224 \\
\hline Korea & 572 & 1735 & 146591 \\
\hline European Patent Office & 340 & 762 & 103326 \\
\hline Germany & 132 & 253 & 50417 \\
\hline Russian Federation & 190 & 329 & 29537 \\
\hline Canada & 154 & 354 & 22030 \\
\hline Australia & 95 & 228 & 16850 \\
\hline France & 40 & 132 & 15200 \\
\hline United Kingdom & 38 & 132 & 13482 \\
\hline Italy & 50 & 135 & 8914 \\
\hline Mexico & 61 & 121 & 7616 \\
\hline Brazil & 40 & 93 & 5080 \\
\hline Spain & 27 & 77 & 4817 \\
\hline Poland & 48 & 154 & 3732 \\
\hline Israel & 10 & 34 & 3551 \\
\hline Finland & 11 & 36 & 1942 \\
\hline Netherlands & 5 & 23 & 1794 \\
\hline Sweden & 4 & 8 & 1692 \\
\hline Austria & 25 & 36 & 1683 \\
\hline Switzerland & 5 & 22 & 1555 \\
\hline Denmark & 12 & 17 & 1199 \\
\hline Norway & 2 & 4 & 1046 \\
\hline Colombia & 4 & 14 & 995 \\
\hline Czech Republic & 7 & 19 & 806 \\
\hline New Zealand & 2 & 14 & 765 \\
\hline Belgium & 4 & 10 & 619 \\
\hline Slovenia & 14 & 20 & 611 \\
\hline Greece & 2 & 13 & 507 \\
\hline Portugal & 6 & 10 & 488 \\
\hline Hungary & 8 & 22 & 452 \\
\hline Slovak Republic & 0 & 5 & 199 \\
\hline Costa Rica & 0 & 0 & 153 \\
\hline Ireland & 0 & 3 & 149 \\
\hline
\end{tabular}


ENV/WKP(2015)10

Table 11. Importance of selected jurisdictions for environment-related technologies

(2009-2011, conservative coverage)

\begin{tabular}{llr}
\hline Rank & Patent office & \% of world's inventions \\
\hline 1 & China & $37.7 \%$ \\
2 & Japan & $32.4 \%$ \\
3 & United States & $25.1 \%$ \\
4 & Korea & $18.4 \%$ \\
5 & European Patent Office & $15.4 \%$ \\
6 & Germany & $9.9 \%$ \\
7 & Chinese Taipei & $3.5 \%$ \\
8 & Canada & $3.4 \%$ \\
9 & Russia & $2.9 \%$ \\
10 & France & $2.6 \%$ \\
\hline$\ldots$ & & \\
18 & Brazil & $0.67 \%$ \\
26 & Eurasian Patent Organization & $0.27 \%$ \\
28 & Argentina & $0.25 \%$ \\
38 & Morocco & $0.10 \%$ \\
40 & Colombia & $0.09 \%$ \\
43 & Peru & $0.07 \%$ \\
44 & African Regional IP Organisation & $0.06 \%$ \\
46 & Egypt & $0.06 \%$ \\
54 & Malaysia & $0.02 \%$ \\
\hline
\end{tabular}

Table 12. Comparison of the importance of jurisdictions as markets vs inventors

(2009-2011, all inventions (PF1))

\begin{tabular}{clc|clc}
\hline Rank & Patent office & $\begin{array}{c}\text { \% of world's ENVTECH inventions } \\
\text { patented in the country by } \\
\text { domestic or foreign applicants }\end{array}$ & Rank & Country & $\begin{array}{c}\text { \% of world's ENVTECH } \\
\text { inventions developed by } \\
\text { the country's inventors }\end{array}$ \\
\hline 1 & China & $37.7 \%$ & 5 & China & $3.9 \%$ \\
2 & Japan & $32.4 \%$ & 3 & Japan & $15.5 \%$ \\
3 & United States & $25.1 \%$ & 1 & United States & $21.1 \%$ \\
4 & Korea & $18.4 \%$ & 2 & Korea & $21.0 \%$ \\
5 & European Patent Office & $15.4 \%$ & $(1)$ & EPO (38 member states) & $28.0 \%$ \\
6 & Germany & $9.9 \%$ & 7 & Chinese Taipei & $12.6 \%$ \\
7 & Chinese Taipei & $3.5 \%$ & 10 & Canada & $3.2 \%$ \\
8 & Canada & $3.4 \%$ & 9 & Russian Federation & $1.6 \%$ \\
9 & Russia & $2.9 \%$ & 6 & France & $2.0 \%$ \\
10 & France & $2.6 \%$ & 27 & Australia & $3.8 \%$ \\
11 & Australia & $2.2 \%$ & 8 & United Kingdom & $0.5 \%$ \\
12 & United Kingdom & $1.9 \%$ & & $2.4 \%$ \\
\hline
\end{tabular}

To further assess patenting activity in environmental technologies compared to patenting overall, and compared to other countries' performance, a measure of the "relative preponderance of patents" (RPP) can be constructed - applying a similar formula to the one used to construct RTA. (An illustrative example is provided below in Section 4.4.) 


\section{EXAMPLES OF POLICY-RELEVANT APPLICATIONS}

\subsection{Understanding the nature of environmental innovation}

Analysing patent data allows the nature of environmental innovation to be better understood. For example, OECD (2010) examined the diversity of engineering fields on which so-called "environmental" technologies draw, and found that environmental technologies draw on a broad range of scientific knowledge (Figure 3). Even science that is not a priori "environmental" might generate knowledge that will be useful for development of environmental technologies. For example, chemistry and material sciences are at least as important as research on energy and the environment. This finding is important as it relates to spending decisions over allocation of $\mathrm{R} \& \mathrm{D}$ budgets aimed at encouraging development of such technologies. while government spending on energy and environment R\&D have not kept pace with the growing urgency of environmental challenges, this do not necessarily imply that more investment is needed in these areas alone. Much transformative innovation results from spill-over effects from other sectors.

Figure 3. The innovation-science link in the develoment of environmental technologies

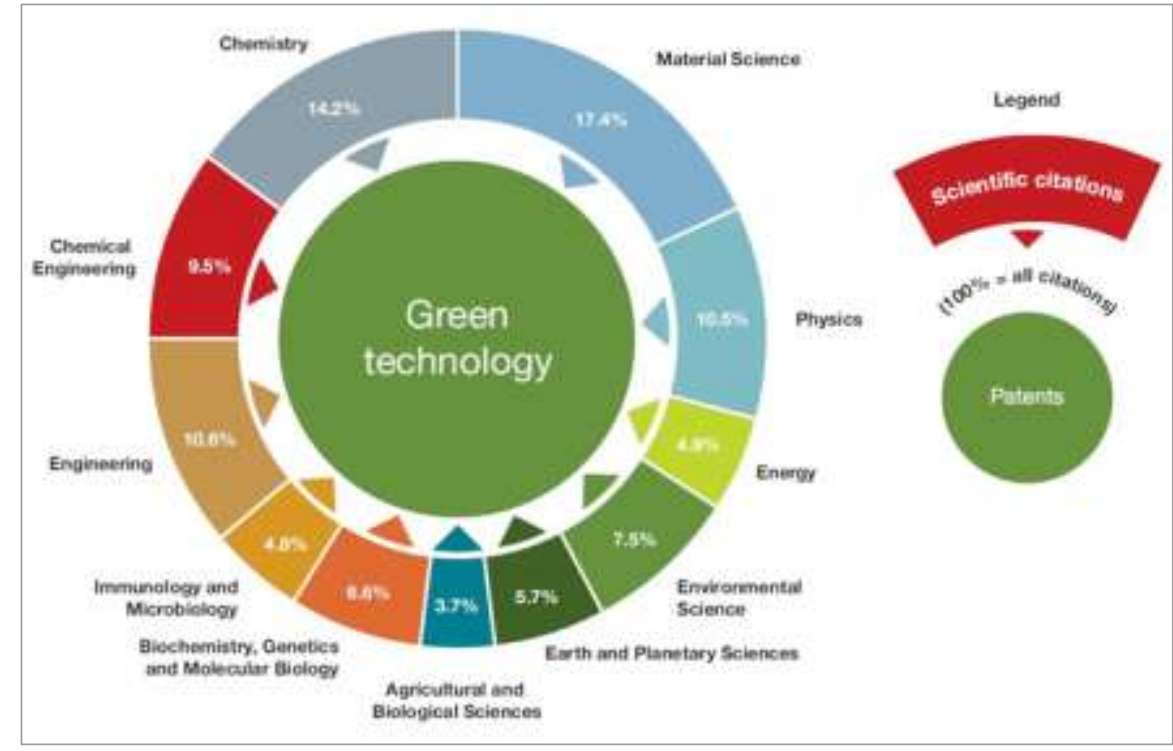

Note: Based on co-citation analysis and matches between "environmental" patents in PATSTAT and cited scientific publications (nonpatent literature) in the SCOPUS database, 2000-07.

Source: OECD (2010), Measuring Innovation - A New Perspective, based on Scopus Custom Data, Elsevier, July 2009; OECD, Patent Database, January 2010; and EPO, Worldwide Patent Statistical Database (PATSTAT), September 2009.

An important question is that of the attributes that best characterise the possible "breakthrough" environmental technologies. Recent work at the OECD examined a number of possible candidate technologies in terms of their originality, radicalness, industrial generality, family size and closeness to science. Preliminary results identify a few very promising technologies, including photovoltaic energy, hydrogen technology and biofuels which appear to have characteristics of ground-breaking technologies. The role of industrial generality emerges as being particularly important with positive implications for downstream success - whether measured as subsequent patent counts, commercial applicability or attractiveness to risk finance (Egli et al. 2015; see also Squicciarini et al. 2013). 


\subsection{Assessment of the role of environmental policy in the development of environmental technologies}

Innovation is an important concept for environmental policy because it should help environmental policy objectives to be achieved at lower costs. However, the ways how environmental policy is implemented in practice will all affect policy effectiveness and efficiency. In particular, the choice of policy instruments (e.g., emission taxes, technology standards, performance standards), their design characteristics (e.g., policy stringency, predictability, flexibility), and timing compared to other countries (first-mover, follower) are all relevant in this regard.. These factors will also determine whether firms' response to the policy will include efforts to develop (and patent) new technological solutions. The broader policy framework (the rule of law, strength of IPR regime, quality of labour force, etc.) also play a role. The good news is that measuring environmental innovation allows these various determinants of environmental innovation to be assessed - and a variety of policy hypotheses to be tested empirically.

At the country level, innovation statistics complement the range of information used for country reviews and allow a country's performance to be better assessed. The 2012 Environmental Performance Review of Germany provides such an example. Figure 4 provides a basis for examining the relations between environmental policy developments and innovative activity.

Figure 4. Inventive activity in solid waste management in Germany

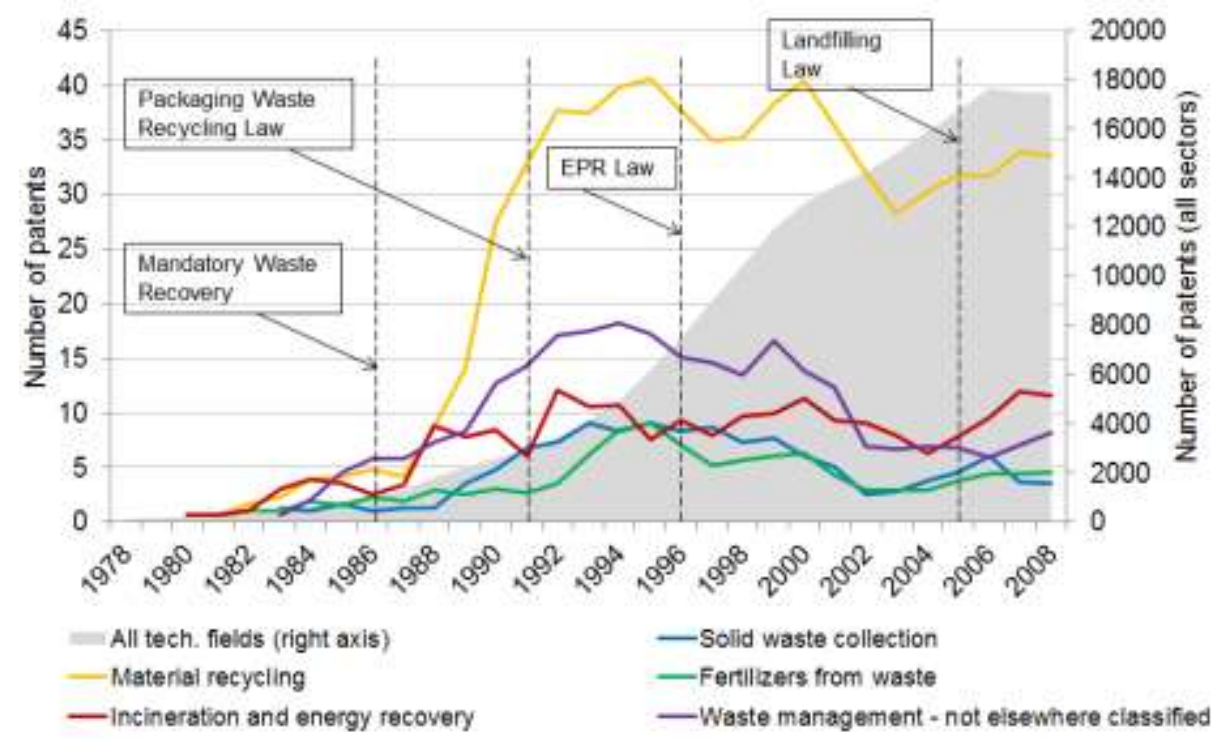

However, potentially a wide range of market and policy determinants might play a role, and descriptive analysis alone might not suffice to discern any correlation between policy shocks and inventive activity, especially in situations when multiple policy instruments are introduced targeting the same environmental objective. Instead, econometric techniques can be used to empirically disentangle the effects of the individual policy instruments. For example, Johnstone et al. (2010) isolate the roles of several policy instrument types and market factors, and find that while public R\&D support has had a statistically significant effect on the development of all of the renewable energy technologies studied, the effect of renewable energy policy instruments varied: On the one hand, renewable energy certificates (portfolio quotas) have been more effective in encouraging development of technologies that are closer to the market (e.g. wind power). This is because when faced with a portfolio quota firms will choose the least-cost means to meet the obligation. On the other hand, targeted feed-in tariffs were more effective in encouraging development of more early-stage technologies (e.g. solar energy). This is because feed-in tariff payments are technology-specific and thus allow incentivising a specific technology, but also because they transfer a 
portion of the associated risk on the government. Such findings help governments make decisions over the appropriate choice of policy instruments.

Figure 5. The choice of policy instruments matters: Estimated effect on inventive activity

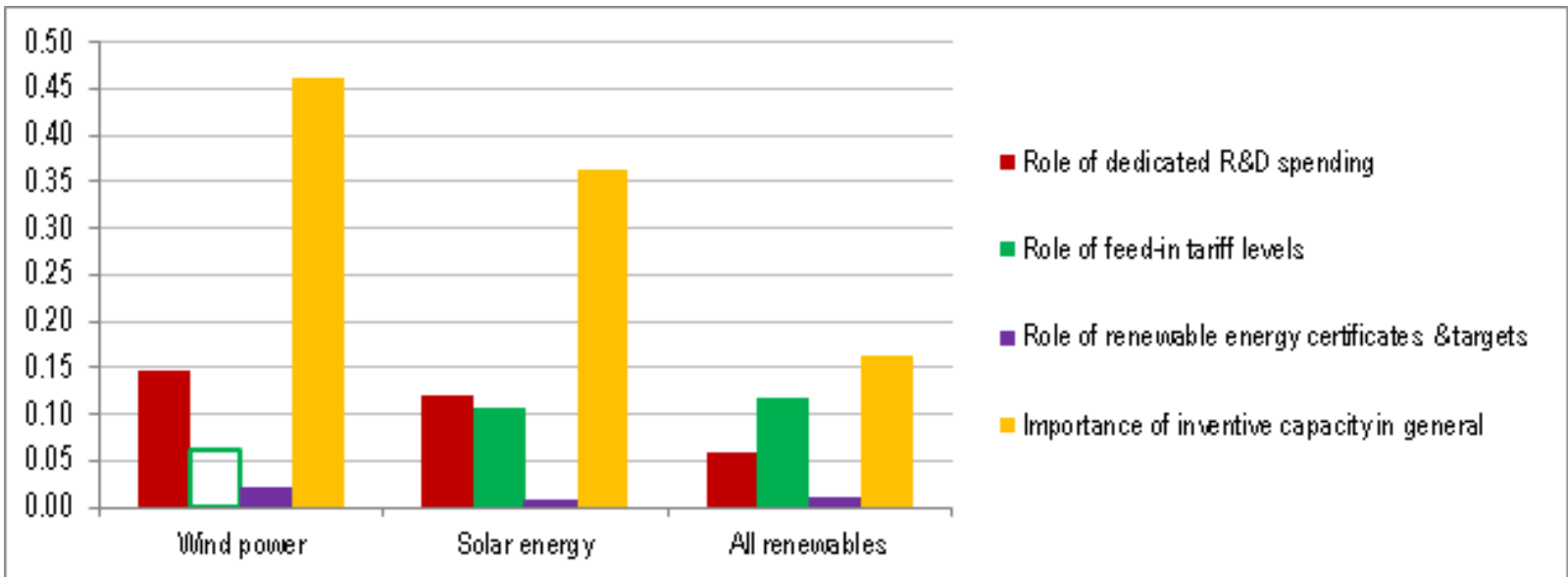

Note: The graph shows estimated elasticities evaluated at sample means. Variables without fill are not statistically significant at the $5 \%$ level. Source: Based on results reported in Johnstone et al. (2010).

Motor vehicle fuel efficiency is another example where multiple policy instruments are directed at the same environmental objective. In OECD (2011) the effect of different policy instruments was examined econometrically while controlling for the role of general inventive capacity as well as varying patent propensities across countries and over time. The results suggest that public R\&D support had a significant impact on the development of both electric and hybrid propulsion technologies. However, while performance standards have been effective in encouraging invention in electric propulsion, they had no effect on hybrid technologies; and conversely, fuel pricing has been effective in encouraging invention in hybrid but not electric vehicles. These findings suggests that appropriate mix of policy instruments is important to encourage both more incremental and more radical innovations - while stringent performance standards might be needed to encourage innovation in technologies at early stages of development, automotive fuel taxes are more suitable (cost-effective) to encourage innovation in technologies closer to market introduction.

Figure 6. The need for a policy mix targeting innovations in vehicle propulsion technologies

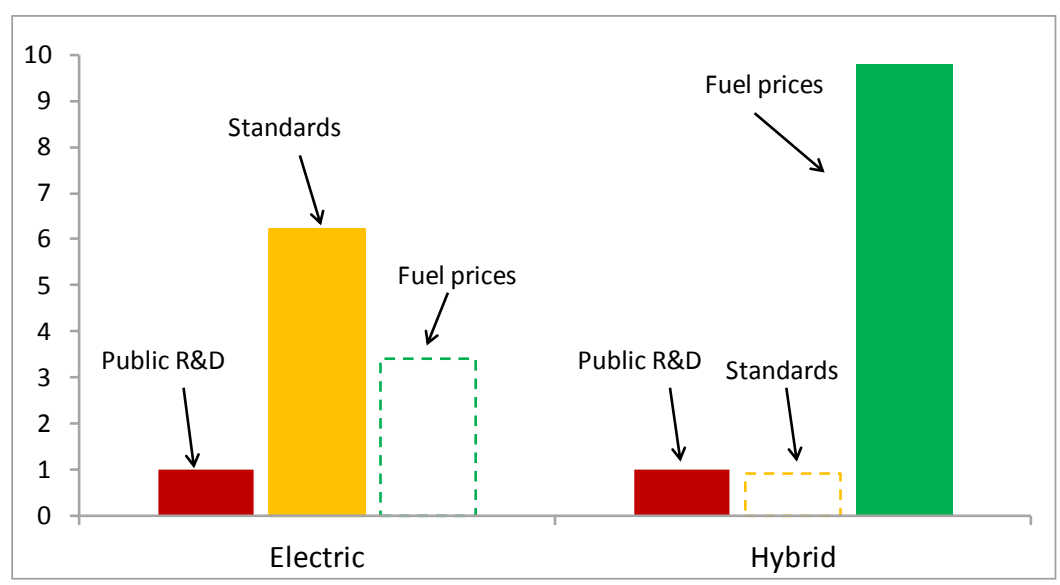

Note: For ease of interpretation the estimated elasticities have been normalised such that effect of $R \& D=1$. Unfilled bars indicate no statistical significance at 5\% level. Source: Haščič and Johnstone (2011a). 
The above examples illustrate how the effect of a policy differs as a function of its stringency and its flexibility (technology neutrality). Generally, policies that do not prescribe the form of abatement means that companies should use provide better incentives for innovation than more prescriptive approaches. Another characteristic that is important is policy predictability - how much uncertainty is there over government action? Does policy provide a stable and predictable signal to firms? One way to approach the question is to study the effect of volatility in public R\&D spending on inventive activity, as in Kalamova et al. (2012) who find evidence of a positive effect for the "level" of R\&D spending and a negative effect for the "volatility" (variance). This suggests that when allocating government funds for R\&D programmes instability in the provision of funding might be detrimental independent of the volume of funding support.

Figure 7. Policy predictability: Estimated effect of volatility in public R\&D on inventive activity

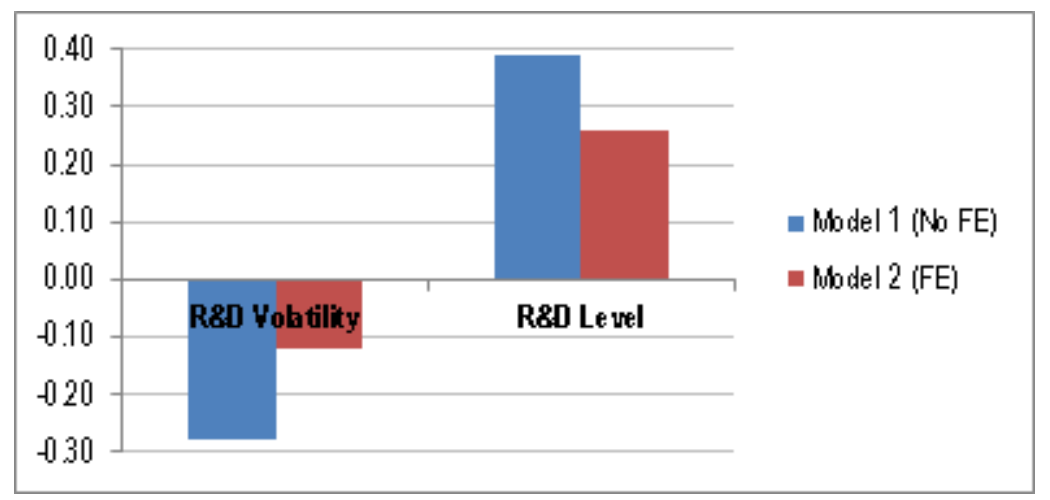

Note: Figure shows the estimated response to a $1 \%$ increase in the level and volatility of public R\&D in encouraging inventive activity in environmental technologies, measured as the number of patent applications (claimed priorities) deposited during 19752007 in a cross-section of OECD countries.

Source: Kalamova et al. (2012)

\subsection{Assessment of the determinants of international collaboration for environmental technologies}

A potentially important and complementary factor in encouraging technology development is international collaboration in science and technology development. This aspect is particularly pertinent in the context of climate change due to its global public good characteristics, implying that there are sizeable potential benefits from collaboration among countries. However, it is also true of technologies which address any environmental impact which crosses borders, whether in terms of pollution emissions (e.g. $\mathrm{SO}_{\mathrm{x}}$ ) or resource flows (e.g. freshwater). While Table 7 provides up-to-date figures, previous analysis based on similar co-invention statistics found that many emerging economies (including India, South Africa, Russia and China) tend to collaborate more often in climate change mitigation than they do in general (in "all technologies"). This is important because given the limited progress in the development of a binding global climate policy to-date, pursuing technology agreements between and among countries is often viewed as a more practical alternative.

Kahrobaie et al. (2012) studied the role of one type of such agreement introduced by the IEA (called "Implementing Agreements"). Controlling for the general tendency of inventors from different countries to collaborate (for example, due to linguistic and geographic proximity, economic ties, etc.), they isolated the effect of a pair of countries jointly participating in an Agreement on the likelihood of mutual co-invention between inventors from the respective countries. Overall, they find a positive effect of the agreements on 
co-invention, although there are important differences across the various climate technology sectors probably linked to the specific design of the Agreements (information sharing, effort sharing) and the nature of technology (extent of public good characteristics, degree of maturity, etc.). This and similar types of analyses might help governments design more effective technology agreements in the future.

Besides public policy, while linguistic and geographic proximity certainly play a role, economic factors seem to be the key determinants of collaboration. For example, one study focusing on Africa found that the co-invention rate in the development of climate change mitigation technologies is $23 \%$ in Africa versus $12 \%$ worldwide, and 9\% worldwide for all technologies (not just climate-related). Hence, while climaterelated technologies are generally characterised by a higher rate of co-invention, this is even more the case in Africa (and particularly in Tunisia, Morocco, Egypt, Kenya and Mali - all of which co-invent at least $50 \%$ of their inventions with inventors in other countries - mostly the US, UK, Belgium, Germany, France, Sweden and Canada). Strikingly, there is very little evidence of intra-Africa co-invention suggesting that every African country is an "island" within the continent (Haščič et al. 2012).

The finding that non-OECD countries produce a greater number of patentable inventions when their researchers collaborate with OECD countries is confirmed by another study that combines patent and bibliometric data (Poirier et al. 2015). This allows the analysis to be taken a step further and examine also knowledge spillovers between OECD and non-OECD countries that seem to benefit particularly nonOECD countries. This finding strengthens the case for international research cooperation between OECD and non-OECD countries in the area of climate mitigation.

\subsection{Assessment of the determinants of market diffusion of environmental technologies}

Encouraging the development of cleaner technologies is only the first step that must be followed by their wide diffusion globally, and their adoption by firms and households, if the promise of reduced environmental impacts is to materialise. Promoting the market diffusion of environmental technologies is therefore a key policy objective. However, new technologies are typically developed in the OECD and other developed countries but the potential for mitigation exists in all countries, and often the most costeffective opportunities lie in emerging and developing economies. Finding ways how to encourage the international transfer of such technologies is therefore a pressing issue. Patent-based indicators can help identify the major drivers (and the potential barriers to) technology transfer; however, the analysis should be placed in wider context and consider also factors such as differences in the strength of IP rights enforcement across countries or differences in the 'patent breadth' across patent offices (e.g., Dechezleprêtre et al. 2011).

For instance, given the important water scarcities in many countries worldwide, what are the major markets for water-related adaptation innovations? Figure 8 presents a specialisation index, calculated as the ratio between the share of water-related patents in each office and the global share of such patents in the field, referred to as the Relative Preponderance to Patent (RPP). A value greater than one indicates that a country is an important market for water technologies, relatively to other technologies. Interestingly, the most water-stressed countries are not always the countries where water technologies are most frequently patented. While Australia, Morocco and Israel are - unsurprisingly - significant markets for water technologies as reflected in patent protection, so are Switzerland, Canada and Brazil, which have large water resources, although regional differences within a country might exist (Figure 8). Moreover, there is no particular correlation between the degree of water stress in a country and the number of water-related patents, suggesting that the diffusion of water-related technologies is currently not particularly directed to countries exposed to water scarcity (Figure 9). This finding however points to the need to promote diffusion of such technologies in countries that are potentially vulnerable to water stress (Dechezleprêtre et al. 2015), for example through appropriate water pricing policies. 
Figure 8. Relative preponderance of water-related adaptation patents

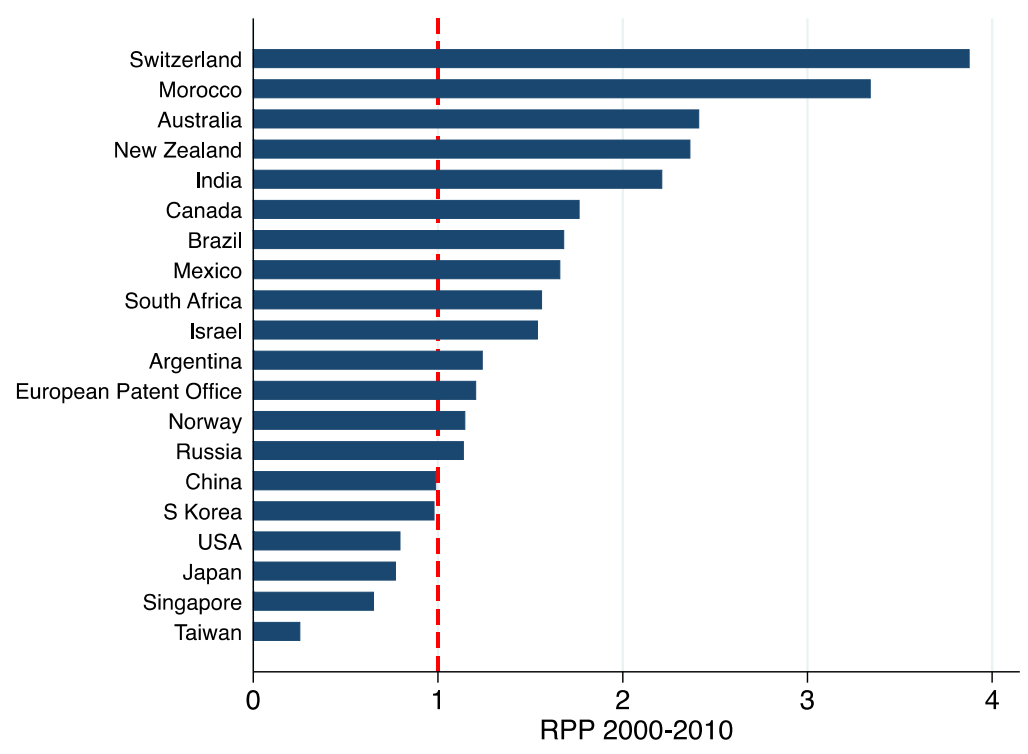

Source: Dechezleprêtre et al. (2015).

Figure 9. Relative preponderance of water-related patents and water vulnerability

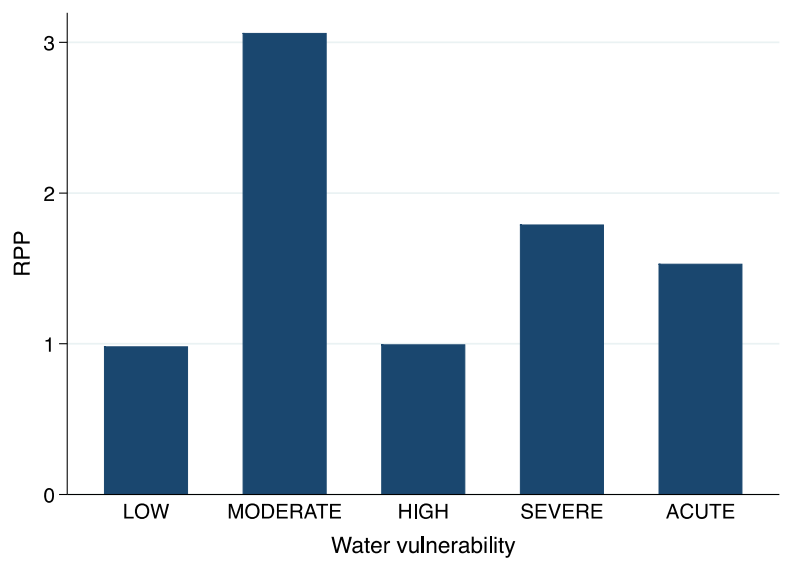

Source: Dechezleprêtre et al. (2015).

In the climate policy domain, the role of the Kyoto Protocol's Clean Development Mechanism (CDM) has been examined using patent data. In one such study, while evidence of a positive effect of the CDM on the international transfer of wind power technologies is found, this effect seems to diminish with each additional CDM project. Interestingly, more than the CDM, the study identified the pivotal role of domestic absorptive capacity - measured using a proxy constructed based on patent data (Figure 10). Encouraging international collaboration in technology development is often seen as a possible means of improving countries' domestic absorptive capacity. 
Figure 10. Encouraging diffusion of wind power technologies

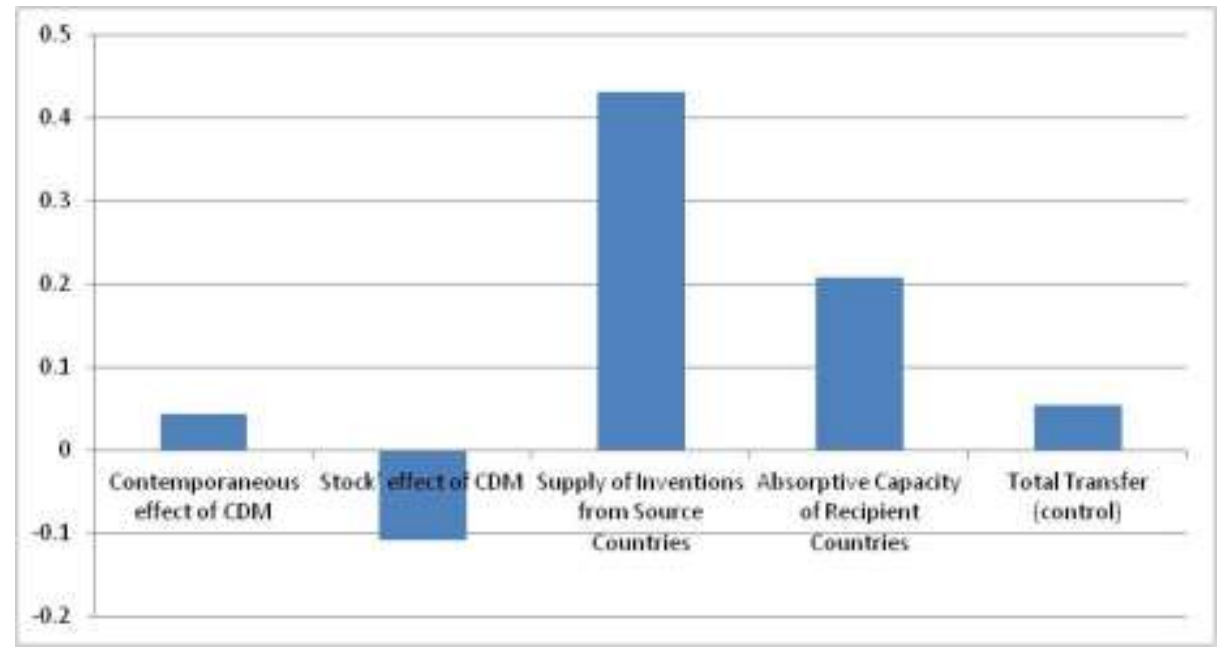

Note: The chart shows estimates of the relative importance of different determinants of transfer of wind power technologies, from Annex I to non-Annex I countries. Source: Haščič and Johnstone (2011b).

It has been sometimes argued that patenting might present a barrier to international technology transfer. The limited empirical evidence available to date raises some serious doubts about this conjecture. For example, a study focusing specifically on patenting in Africa showed that while the rates of protection of climate technologies in African markets are high relative to patenting of other technologies, the actual number of inventions that are protected in African markets is very small - only about $1 \%$ of world's patents for climate change mitigation and adaptation technologies - providing evidence that patents are not a barrier to technology transfer and diffusion (EPO/UNEP 2013a; Haščič et al. 2012). Weak enforcement of IP rights and weak domestic policy demand for such technologies likely play a role. Similar results were provided by another study focused on the Latin American region which found that less than $2 \%$ of climate change-related patent families were patented in countries of Latin America (EPO/UNEP 2013b). Such low level of patent protection is unlikely to hamper technology transfer to developing countries. These studies could be usefully complemented by econometric analysis that would permit to test empirically the hypothesis about a possible causality between patenting and international trade, and the direction of the causality. 


\section{REFERENCES}

Dechezleprêtre, A., I. Haščič and N. Johnstone (2015), "Invention and International Diffusion of Water Conservation and Availability Technologies: Evidence from Patent Data", OECD Environment Working Papers, No. 82, OECD Publishing, Paris, http://dx.doi.org/10.1787/5js679fvllhg-en.

Dechezleprêtre, A., M. Glachant, I. Haščič, N. Johnstone and Y. Ménière (2011), "Invention and transfer of climate change mitigation technologies on a global scale: A study drawing on patent data", Review of Environmental Economics and Policy, Volume 5, Issue 1, Pages 109-130.

Dernis, H., D. Guellec and B. van Pottelsberghe de la Potterie (2001), "Using Patent Counts for Crosscountry Comparisons of Technology Output”, STI Review, No. 27, pp. 129-146, OECD.

Egli, F., N. Johnstone, and C. Menon (2015, forthcoming), "Identifying and Inducing Breakthrough Inventions: An Application Related to Climate Change Mitigation", OECD Science, Technology and Industry Working Papers, OECD Publishing, Paris.

EPO (2014), Worldwide Patent Statistical Database (PATSTAT), December 2014 edition. European Patent Office.

EPO/UNEP (2013a), "Patents and clean energy technologies in Africa", www.epo.org/papers/africareport/page88.html\#/0.

EPO/UNEP (2013b), "Patents and climate change mitigation technologies in Latin America and the Caribbean".

EPO/UNEP/ICTSD (2010), "Patents and clean energy: bridging the gap between evidence and policy", http://documents.epo.org/projects/babylon/eponet.nsf/0/cc5da4b168363477c12577ad00547289/\$FI LE/patents_clean_energy_study_en.pdf.

Faust, K. (1990), "Early identIfication of Technological Advances on the Basis of Patent Data", Scientometrics, Vol. 19(5-6), pp. 473-480.

Faust, K. and H. Schedl (1983), "International Patent Data: Their Utilisation for the Analysis of Technological Developments", World Patent Information, Vol. 5(3), pp. 144-157.

Griliches, Z. (1990), "Patent Statistics as Economic Indicators: A Survey", Journal of Economic Literature, Vol. 28, No. 4, pp. 1661-1707.

Guellec, D. and B. van Pottelsberghe de la Potterie, (2000), “Applications, grants and the value of a patent", Economics Letters 69, 109-114.

Harhoff, D., F.M. Scherer, Vopel, K. (2003), "Citations, family size, opposition and the value of patent rights", Research Policy 32, 1343-1363.

Haščič, I., J. Silva and N. Johnstone (2015, forthcoming), "Patent Statistics for International Comparisons and Analysis of Narrow Technological Fields," OECD Science, Technology and Industry Working Papers, OECD Publishing, Paris. 
Haščič, I., J. Silva and N. Johnstone (2012), "Climate Mitigation and Adaptation in Africa: Evidence from Patent Data", OECD Environment Working Papers, No. 50, OECD Publishing, Paris, http://dx.doi.org/10.1787/5k8zng5smxjg-en .

Haščič, I. and N. Johnstone (2011a), "Innovation in Electric and Hybrid Vehicle Technologies: The Role of Prices, Standards and R\&D”, in OECD, Invention and Transfer of Environmental Technologies, OECD Publishing, Paris, http://dx.doi.org/10.1787/9789264115620-5-en .

Haščič, I. and N. Johnstone (2011b), The Clean Development Mechanism and international technology transfer: Empirical evidence on wind power", Climate Policy, Volume 11, Issue 6, Pages 1303-1314.

Haščič, I., et al. (2010), "Climate Policy and Technological Innovation and Transfer: An Overview of Trends and Recent Empirical Results", OECD Environment Working Papers, No. 30, OECD Publishing, Paris, http://dx.doi.org/10.1787/5km33bnggcd0-en

Johnstone, N., I. Haščič and D. Popp (2010), "Renewable energy policies and technological innovation: Evidence based on patent counts", Environmental and Resource Economics, Volume 45, Issue 1, Pages 133-155, www.springerlink.com/content/31530165m2382l28/.

Johnstone, N. (ed.) (2007), Environmental Policy and Corporate Behaviour, Edward Elgar.

Kahrobaie, N., I. Haščič and N. Johnstone (2012), "International technology agreements for climate change: Analysis based on co-invention data", in OECD, Energy and Climate Policy: Bending the Technological Trajectory, OECD Publishing, Paris, http://dx.doi.org/10.1787/9789264174573-8-en

Kalamova, M., N. Johnstone and I. Haščič (2012), "Implications of Policy Uncertainty for Innovation in Environmental Technologies: The Case of Public R\&D Budgets" in: The Dynamics of Environmental and Economic Systems - Innovation, Environmental Policy and Competitiveness, edited by Valeria Costantini and Massimiliano Mazzanti, 2013, Chapter 6, Pages 99-116, Springer Publ., http://link.springer.com/chapter/10.1007/978-94-007-5089-0_6.

Meyer, M. (2002), “Tracing Knowledge Flows in Innovation Systems”, Scientometrics 54(2): 193-212.

OECD (2014a), Green Growth Indicators 2014, OECD Green Growth Studies, OECD Publishing, Paris, http://dx.doi.org/10.1787/9789264202030-en.

OECD (2014b), Main Science and Technology Indicators, Vol. 2014/1, OECD Publishing, Paris, http://dx.doi.org/10.1787/msti-v2014-1-en.

OECD (2012), Energy and Climate Policy: Bending the Technological Trajectory, OECD Studies on Environmental Innovation, OECD Publishing, Paris, http://dx.doi.org/10.1787/9789264174573-en.

OECD (2011), Invention and Transfer of Environmental Technologies, OECD Studies on Environmental Innovation, OECD Publishing, Paris, http://dx.doi.org/10.1787/9789264115620-en.

OECD (2010), Measuring Innovation: A New Perspective, OECD Publishing, Paris, http://dx.doi.org/10.1787/9789264059474-en.

OECD (2009), OECD Patent Statistics Manual, OECD Publishing, Paris, http://dx.doi.org/10.1787/9789264056442-en. 
OECD (2008), Environmental Policy, Technological Innovation and Patents, OECD Studies on Environmental Innovation, OECD Publishing, Paris, http://dx.doi.org/10.1787/9789264046825-en.

OECD (2002), Frascati Manual 2002: Proposed Standard Practice for Surveys on Research and Experimental Development, The Measurement of Scientific and Technological Activities, OECD Publishing, Paris, http://dx.doi.org/10.1787/9789264199040-en.

OECD/Eurostat (1999), The Environmental Goods and Services Industry: Manual for Data Collection and Analysis, OECD Publishing, Paris, http://dx.doi.org/10.1787/9789264173651-en.

Poirier, J., Johnstone, N., I. Haščič and J. Silva (2015), "The Benefits of International Co-Authorship in Scientific Papers: The Case of Wind Energy Technologies", OECD Environment Working Papers, No. 81, OECD Publishing, Paris, http://dx.doi.org/10.1787/5js69ld9w9nv-en.

Rollinson, J. and R. Heijna (2006), "EPO Worldwide Patent Statistical Database (PATSTAT)", presentation at the EPO and OECD Conference on Patent Statistics for Policy Decision Making, Vienna, Austria.

Rollinson, J. and D. Lingua (2007), "The Development of PATSTAT", presentation at the EPO and OECD Conference Patent Statistics for Policy Decision Making, Venice, Italy, October.

Squicciarini, M., H. Dernis and C. Criscuolo (2013), "Measuring patent quality: Indicators of technological and economic value", OECD Science, Technology and Industry Working Papers, No. 2013/03, OECD Publishing, Paris, http://dx.doi.org/10.1787/5k4522wkw1r8-en.

Veefkind, V., J. Hurtado-Albir, S. Angelucci, K. Karachalios and N. Thumm (2012), “A new EPO classification scheme for climate change mitigation technologies", World Patent Information, Volume 34, Issue 2, Pages 106 - 111. 
ENV/WKP(2015)10

\section{ANNEX - PATENT SEARCH STRATEGIES}

\section{Search Strategies for the Identification of Selected Environment-Related Technologies (ENV-TECH)}

\begin{tabular}{|c|c|}
\hline 1. ENVIRONMENTAL MANAGEMENT & IPC class \\
\hline 1.1. AIR POLLUTION ABATEMENT & $\begin{array}{l}\text { All classes from } \\
1.1 .1 \text { to } 1.1 .3\end{array}$ \\
\hline \multicolumn{2}{|l|}{ 1.1.1. Emissions abatement from stationary sources (e.g. SOx, NOx, PM emissions from combustion plants) } \\
\hline \multicolumn{2}{|l|}{ Post-combustion technologies } \\
\hline $\begin{array}{l}\text { Chemical or biological purification of waste gases ( e.g. engine exhaust gases, smoke, fumes, flue gases or aerosols; removing sulfur } \\
\text { oxides, nitrogen oxides, etc.) }\end{array}$ & B01D53/34-72 \\
\hline Incinerators or other apparatus specially adapted for consuming waste gases or noxious gases & F23G7/06 \\
\hline Arrangements of devices for treating smoke or fumes of purifiers, e.g. for removing noxious material & F23J15 \\
\hline Shaft or like vertical or substantially vertical furnaces; Arrangements of dust collectors & F27B1/18 \\
\hline \multicolumn{2}{|l|}{ Integrated technologies } \\
\hline Blast furnaces; Dust arresters & $\mathrm{C} 21 \mathrm{~B} 7 / 22$ \\
\hline Manufacture of carbon steel, e.g. plain mild steel, medium carbon steel, or cast-steel; Removal of waste gases or dust & C21C5/38 \\
\hline Combustion apparatus characterised by means for returning flue gases to the combustion chamber or to the combustion zone & F23B80 \\
\hline Combustion apparatus characterised by arrangements for returning combustion products or flue gases to the combustion chamber & F23C9 \\
\hline Apparatus in which combustion takes place in a fluidised bed of fuel or other particles & $\mathrm{F} 23 \mathrm{C} 10$ \\
\hline \multicolumn{2}{|l|}{ 1.1.2. Emissions abatement from mobile sources (e.g. $\mathrm{NOx}, \mathrm{CO}, \mathrm{HC}, \mathrm{PM}$ emissions from motor vehicles) } \\
\hline \multicolumn{2}{|l|}{ Post-combustion technologies } \\
\hline Processes, apparatus or devices specially adapted for purification of engine exhaust gases & B01D53/92 \\
\hline ...by catalytic processes & B01D53/94 \\
\hline Regeneration, reactivation or recycling of reactants & B01D53/96 \\
\hline Catalysts comprising metals or metal oxides or hydroxides; of noble metals; of the platinum group metals & B01J23/38-46 \\
\hline Crankcase ventilating or breathing & F01M13/02-04 \\
\hline $\begin{array}{l}\text { Methods of operating engines involving adding non-fuel substances including exhaust gas to combustion air, fuel, or fuel-air mixtures of } \\
\text { engines; the substances including exhaust gas }\end{array}$ & F02B47/08-10 \\
\hline $\begin{array}{l}\text { Controlling engines characterised by their being supplied with non-fuel gas added to combustion-air, such as the exhaust gas of engine, } \\
\text { or having secondary air added to fuel-air mixture }\end{array}$ & F02D21/06-10 \\
\hline Engine-pertinent apparatus for adding exhaust gases to combustion-air, main fuel, or fuel-air mixture & F02M25/07 \\
\hline Testing of internal-combustion engines by monitoring exhaust gases & G01M15/10 \\
\hline \multicolumn{2}{|l|}{ Integrated technologies } \\
\hline $\begin{array}{l}\text { Methods of operating engines involving adding non-fuel substances or anti-knock agents to combustion air, fuel, or fuel-air mixtures of } \\
\text { engines; the substances including non-airborne oxygen }\end{array}$ & F02B47/06 \\
\hline Electrical control of supply of combustible mixture or its constituents & F02D41 \\
\hline Conjoint electrical control of two or more functions, e.g. ignition, fuel-air mixture, recirculation, supercharging, exhaust-gas treatment & F02D43 \\
\hline Electrical control of combustion engines & F02D45 \\
\hline Idling devices for preventing flow of idling fuel & F02M3/02-055 \\
\hline Apparatus for adding secondary air to fuel-air mixture. & F02M23 \\
\hline $\begin{array}{l}\text { Engine-pertinent apparatus for adding non-fuel substances or small quantities of secondary fuel to combustion-air, main fuel, or fuel-air } \\
\text { mixture. }\end{array}$ & F02M25 \\
\hline Apparatus for treating combustion-air, fuel, or fuel-air mixture, by catalysts, electric means, magnetism, rays, sonic waves, etc. & F02M27 \\
\hline Apparatus for thermally treating combustion-air, fuel, or fuel-air mixture & F02M31/02-18 \\
\hline Fuel-injection apparatus & F02M39-71 \\
\hline Advancing or retarding ignition; Control therefore & F02P5 \\
\hline
\end{tabular}


ENV/WKP(2015)10

\begin{tabular}{|c|c|}
\hline 1.1.3. Not elsewhere classified 24 & \\
\hline Post-combustion technologies & \\
\hline Filters or filtering processes specially modified for separating dispersed particles from gases or vapours & B01D46 \\
\hline Separating dispersed particles from gases, air or vapours by liquid as separating agent & B01D47 \\
\hline Separating dispersed particles from gases, air or vapours by other methods & B01D49 \\
\hline Combinations of devices for separating particles from gases or vapours & B01D50 \\
\hline Auxiliary pre-treatment of gases or vapours to be cleaned from dispersed particles & B01D51 \\
\hline Separating dispersed particles from gases or vapour, e.g. air, by electrostatic effect & B03C3 \\
\hline Exhaust or silencing apparatus having means for purifying or rendering innocuous & F01N3 \\
\hline Exhaust or silencing apparatus combined or associated with devices profiting by exhaust energy & F01N5 \\
\hline Exhaust or silencing apparatus, or parts thereof & F01N7 \\
\hline Exhaust or silencing apparatus characterised by constructional features & F01N13 \\
\hline Electrical control of exhaust gas treating apparatus & F01N9 \\
\hline Monitoring or diagnostic devices for exhaust-gas treatment apparatus & F01N11 \\
\hline Integrated technologies & \\
\hline Use of additives to fuels or fires for particular purposes for reducing smoke development & C10L10/02 \\
\hline Use of additives to fuels or fires for particular purposes for facilitating soot removal & C10L10/06 \\
\hline 1.2. WATER POLLUTION ABATEMENT & $\begin{array}{l}\text { All classes from } \\
1.2 .1 \text { to } 1.2 .3\end{array}$ \\
\hline 1.2.1. Water and wastewater treatment & \\
\hline Arrangements of installations for treating waste-water or sewage & B63J4 \\
\hline Treatment of water, waste water, sewage or sludge & $\mathrm{CO} 2 \mathrm{~F}$ \\
\hline Chemistry; Materials for treating liquid pollutants, e.g. oil, gasoline, fat & C09K3/32 \\
\hline Plumbing installations for waste water & $\mathrm{E} 03 \mathrm{C} 1 / 12$ \\
\hline Sewers - Cesspools & E03F \\
\hline 1.2.2. Fertilizers from wastewater & \\
\hline Fertilisers from waste water, sewage sludge, sea slime, ooze or similar masses & $\mathrm{C} 05 \mathrm{~F} 7$ \\
\hline 1.2.3. Oil spill cleanup & \\
\hline $\begin{array}{l}\text { Devices for cleaning or keeping clear the surface of open water from oil or like floating materials by separating or removing these } \\
\text { materials }\end{array}$ & E02B15/04-10 \\
\hline Vessels or like floating structures adapted for special purposes - for collecting pollution from open water & B63B35/32 \\
\hline Materials for treating liquid pollutants, e.g. oil, gasoline or fat & $\operatorname{cogK} 3 / 32$ \\
\hline 1.3. WASTE MANAGEMENT & $\begin{array}{l}\text { All classes from } \\
1.3 .1 \text { to } 1.3 .6\end{array}$ \\
\hline 1.3.1. Solid waste collection & \\
\hline Street cleaning; Removing undesirable matter, e.g. rubbish, from the land, not otherwise provided for & $\mathrm{E} 01 \mathrm{H} 15$ \\
\hline Transporting; Gathering or removal of domestic or like refuse & B65F \\
\hline 1.3.2. Material recovery, recycling and re-use & \\
\hline Animal feeding-stuffs from distillers' or brewers' waste; waste products of dairy plant; meat, fish, or bones; from kitchen waste & A23K1/06-10 \\
\hline Footwear made of rubber waste & $\mathrm{A} 43 \mathrm{~B} 1 / 12$ \\
\hline Heels or top-pieces made of rubber waste & A43B21/14 \\
\hline Separating solid materials; General arrangement of separating plant specially adapted for refuse & B03B9/06 \\
\hline
\end{tabular}

\footnotetext{
${ }^{24}$ Including technologies potentially applicable to both stationary and mobile sources
} 
ENV/WKP(2015)10

\begin{tabular}{|c|c|}
\hline Manufacture of articles from scrap or waste metal particles & B22F8 \\
\hline Preparing material; Recycling the material & B29B7/66 \\
\hline Recovery of plastics or other constituents of waste material containing plastics & B29B17 \\
\hline Presses specially adapted for consolidating scrap metal or for compacting used cars & B30B9/32 \\
\hline Systematic disassembly of vehicles for recovery of salvageable components, e.g. for recycling & B62D67 \\
\hline Stripping waste material from cores or formers, e.g. to permit their re-use & $\mathrm{B} 65 \mathrm{H} 73$ \\
\hline Applications of disintegrable, dissolvable or edible materials & B65D65/46 \\
\hline Compacting the glass batches, e.g. pelletizing & C03B1/02 \\
\hline Glass batch composition - containing silicates, e.g. cullet & $\mathrm{C} 03 \mathrm{C} 6 / 02$ \\
\hline Glass batch composition - containing pellets or agglomerates & $\mathrm{C03C6/08}$ \\
\hline Hydraulic cements from oil shales, residues or waste other than slag & $\mathrm{C} 04 \mathrm{~B} 7 / 24-30$ \\
\hline Calcium sulfate cements starting from phosphogypsum or from waste, e.g. purification products of smoke & C04B11/26 \\
\hline Use of agglomerated or waste materials or refuse as fillers for mortars, concrete or artificial stone; Waste materials or Refuse & C04B18/04-10 \\
\hline Clay-wares; Waste materials or Refuse & C04B33/132 \\
\hline Recovery or working-up of waste materials (plastics) & C08J11 \\
\hline Luminescent, e.g. electroluminescent, chemiluminescent, materials; Recovery of luminescent materials & C09K11/01 \\
\hline Working-up used lubricants to recover useful products & C10M175 \\
\hline Working-up raw materials other than ores, e.g. scrap, to produce non-ferrous metals or compounds thereof & $\mathrm{C} 22 \mathrm{~B} 7$ \\
\hline Obtaining zinc or zinc oxide; From muffle furnace residues; From metallic residues or scraps & C22B19/28-30 \\
\hline Obtaining tin; From scrap, especially tin scrap & $\mathrm{C} 22 \mathrm{~B} 25 / 06$ \\
\hline Textiles; Disintegrating fibre-containing articles to obtain fibres for re-use & D01G11 \\
\hline Paper-making; Fibrous raw materials or their mechanical treatment - using waste paper & $\mathrm{D} 21 \mathrm{~B} 1 / 08-10$ \\
\hline Paper-making; Fibrous raw materials or their mechanical treatment; Defibrating by other means - of waste paper & $\mathrm{D} 21 \mathrm{~B} 1 / 32$ \\
\hline Paper-making; Other processes for obtaining cellulose; Working-up waste paper & $\mathrm{D} 21 \mathrm{C} 5 / 02$ \\
\hline Paper-making; Pulping; Non-fibrous material added to the pulp; Waste products & $\mathrm{D} 21 \mathrm{H} 17 / 01$ \\
\hline Apparatus or processes for salvaging material from electric cables & H01B 15/00 \\
\hline Recovery of material from discharge tubes or lamps & H01J 9/52 \\
\hline Reclaiming serviceable parts of waste cells or batteries & H01M 6/52 \\
\hline Reclaiming serviceable parts of waste accumulators & H01M 10/54 \\
\hline \multicolumn{2}{|l|}{ 1.3.3. Fertilizers from waste } \\
\hline Fertilisers made from animal corpses, or parts thereof & C05F1 \\
\hline Fertilisers from distillery wastes, molasses, vinasses, sugar plant, or similar wastes or residues & C05F5 \\
\hline Fertilisers from waste water, sewage sludge, sea slime, ooze or similar masses & $\mathrm{C} 05 \mathrm{~F} 7$ \\
\hline Fertilizers from household or town refuse & C05F9 \\
\hline Preparation of fertilizers characterized by the composting step & C05F17 \\
\hline \multicolumn{2}{|l|}{ 1.3.4. Incineration and energy recovery } \\
\hline $\begin{array}{l}\text { Solid fuels essentially based on materials of non-mineral origin; on sewage, house, or town refuse; on industrial residues or waste } \\
\text { materials }\end{array}$ & C10L5/46-48 \\
\hline Cremation furnaces; Incineration of waste; Incinerator constructions; Details, accessories or control therefor & F23G5 \\
\hline Cremation furnaces; Incinerators or other apparatus specially adapted for consuming specific waste or low grade fuels & F23G7 \\
\hline \multicolumn{2}{|l|}{ 1.3.5. Landfilling } \\
\hline $\begin{array}{l}\text { [Search strategy currently not available] } \\
\text { Note: Landfilling patents are largely covered by IPC class B09B. However, this class also covers many aspects of recycling and } \\
\text { incineration. Therefore, B09B is only used to generate aggregate 'waste management' counts. }\end{array}$ & \\
\hline
\end{tabular}


ENV/WKP(2015)10

\begin{tabular}{|l|l|}
\hline 1.3.6. Waste management - Not elsewhere classified & \\
\hline Disposal of solid waste & B09B \\
\hline Production of liquid hydrocarbon mixtures from rubber or rubber waste & C10G1/10 \\
\hline Medical or veterinary science; Disinfection or sterilising methods specially adapted for refuse & A61L11 \\
\hline 1.4. SOIL REMEDIATION & \\
\hline Reclamation of contaminated soil & B09C \\
\hline 1.5. ENVIRONMENTAL MONITORING & \\
\hline Monitoring or diagnostic devices for exhaust-gas treatment apparatus & F01N11 \\
\hline Alarms responsive to a single specified undesired or abnormal condition and not otherwise provided for, e.g. pollution alarms; toxics & G08B21/12-14 \\
\hline Note: This search strategy is under development, the counts generated are most likely incomplete. & \\
\hline
\end{tabular}

\begin{tabular}{|c|c|}
\hline 2. WATER-RELATED ADAPTATION TECHNOLOGIES & IPC or CPC class \\
\hline \multicolumn{2}{|l|}{ 2.1. DEMAND-SIDE TECHNOLOGIES (water conservation) } \\
\hline \multicolumn{2}{|l|}{ 2.1.1. Indoor water conservation } \\
\hline \multicolumn{2}{|l|}{ Faucets and showers } \\
\hline \multicolumn{2}{|l|}{ Self-closing valves } \\
\hline $\begin{array}{l}\text { Self-closing valves, i.e. closing automatically after operation, in which the closing movement, either retarded or not, starts immediately } \\
\text { after opening }\end{array}$ & F16K21/06-12 \\
\hline Self-closing valves, i.e. closing automatically after operation, closing after a predetermined quantity of fluid has been delivered & F16K 21/16-20 \\
\hline \multicolumn{2}{|l|}{ Aeration of water } \\
\hline Arrangement or mounting of devices, e.g. valves, for venting or aerating or draining & F16L 55/07 \\
\hline Jet regulators with aerating means & E03C 1/084 \\
\hline \multicolumn{2}{|l|}{ Sanitation (dual-flush toilets, dry toilets, closed-circuit toilets) } \\
\hline Flushing devices discharging variable quantities of water & E03D 3/12 \\
\hline Cisterns discharging variable quantities of water & E03D 1/14 \\
\hline Urinals without flushing & A47K 11/12 \\
\hline Dry closets & A47K 11/02 \\
\hline Waterless or low-flush urinals & E03D13/007 \\
\hline Special constructions of flushing devices with recirculation of bowl-cleaning fluid & E03D5/016 \\
\hline \multicolumn{2}{|l|}{ Greywater } \\
\hline Greywater supply systems & E03B1/041 \\
\hline \multicolumn{2}{|l|}{ Home appliances } \\
\hline Optimisation of water quantity (for dishwashers) & Y02B 40/46 \\
\hline Optimisation of water quantity (for washing machines) & Y02B 40/56 \\
\hline \multicolumn{2}{|l|}{ 2.1.2. Irrigation water conservation } \\
\hline \multicolumn{2}{|l|}{ Drip irrigation } \\
\hline $\begin{array}{l}\text { Watering arrangements located above the soil which make use of perforated pipe-lines or pipe-lines with dispensing fittings, e.g. for drip } \\
\text { irrigation }\end{array}$ & A01G 25/02 \\
\hline Watering arrangements making use of perforated pipe-lines located in the soil & A01G 25/06 \\
\hline
\end{tabular}


ENV/WKP(2015)10

\begin{tabular}{|c|c|}
\hline \multicolumn{2}{|l|}{ Control of watering } \\
\hline Control of watering & A01G 25/16 \\
\hline \multicolumn{2}{|l|}{ Drought-resistant crops } \\
\hline $\begin{array}{l}\text { Mutation or genetic engineering; DNA or RNA concerning genetic engineering, vectors, e.g. plasmids, or their isolation, preparation or } \\
\text { purification; for drought, cold, salt resistance }\end{array}$ & C12N15/8273 \\
\hline \multicolumn{2}{|l|}{ 2.1.3. Water conservation in thermoelectric power production } \\
\hline Combustion heat from one cycle heating the fluid in another cycle & F01K 23/08-10 \\
\hline $\begin{array}{l}\text { Non-positive-displacement machines or engines, e.g. steam turbines / Preventing or minimizing internal leakage of working fluid, e.g. } \\
\text { between stages }\end{array}$ & F01D 11 \\
\hline \multicolumn{2}{|l|}{ 2.1.4. Water distribution } \\
\hline \multicolumn{2}{|l|}{ Piping - reducing leakage and leakage monitoring } \\
\hline Pipe-line systems / Protection or supervision of installations / Preventing, monitoring, or locating loss & [F17D5/02 and E03] \\
\hline Devices for covering leaks in pipes or hoses, e.g. hose-menders & $\begin{array}{l}\text { [F16L55/16 and } \\
\text { E03] }\end{array}$ \\
\hline Investigating fluid tightness of structures, by detecting the presence of fluid at the leakage point & $\begin{array}{l}\text { [G01M 3/08 or } \\
\text { G01M 3/14 or } \\
\text { G01M 3/18 or } \\
\text { G01M 3/22 or } \\
\text { G01M 3/28] and } \\
\text { E03 } \\
\end{array}$ \\
\hline \multicolumn{2}{|l|}{ 2.2. SUPPLY-SIDE TECHNOLOGIES (water availability) } \\
\hline \multicolumn{2}{|l|}{ 2.2.1. Water collection (rain, surface and ground-water) } \\
\hline \multicolumn{2}{|l|}{ Underground water collection } \\
\hline Use of pumping plants or installations & E03B 5 \\
\hline Methods or installations for obtaining or collecting drinking water or tap water from underground & E03B 3/06-26 \\
\hline \multicolumn{2}{|l|}{ Surface water collection } \\
\hline Methods or installations for drawing-off water & E03B 9 \\
\hline Methods or installations for obtaining or collecting drinking water or tap water from surface water & E03B 3/04; 28-38 \\
\hline \multicolumn{2}{|l|}{ Rainwater water collection } \\
\hline Methods or installations for obtaining or collecting drinking water or tap water from rainwater & E03B 3/02 \\
\hline Special vessels for collecting or storing rain-water for use in the household, e.g. water-butts & E03B 3/03 \\
\hline \multicolumn{2}{|l|}{ Not elsewhere classified } \\
\hline Methods or installations for obtaining or collecting drinking water or tap water; rainwater, surface water, or groundwater & \begin{tabular}{|l|l|} 
E03B 3/00 \\
E03B 3/40
\end{tabular} \\
\hline \multicolumn{2}{|l|}{ 2.2.2. Water storage } \\
\hline Arrangements or adaptations of tanks for water supply & E03B 11 \\
\hline \multicolumn{2}{|l|}{ 2.2.3. Desalination of sea water } \\
\hline [Search strategy under development] & \\
\hline
\end{tabular}

3. BIODIVERSITY PROTECTION AND ECOSYSTEM HEALTH 
ENV/WKP(2015)10

\begin{tabular}{|c|c|}
\hline 4. CLIMATE CHANGE MITIGATION technologies related to ENERGY generation, transmission of distribution & Y02E \\
\hline 4.1. RENEWABLE ENERGY GENERATION & Y02E10 \\
\hline 4.1.1. Wind energy & Y02E10/70 \\
\hline $\begin{array}{ll}\text { - } & \text { Wind turbines with rotation axis in wind direction: blades or rotors, components or gearbox, control of turbines, generator, } \\
\text { nacelles, onshore and offshore towers } \\
\text { - } \quad \text { Wind turbines with rotation axis perpendicular to the wind direction } \\
\text { - } \quad \text { Power conversion electric or electronic aspects; for grid-connected applications; concerning power management inside } \\
\text { the plant, e.g. battery (dis)charging, operation, hybridisation }\end{array}$ & Y02E10/70-766 \\
\hline 4.1.2. Solar thermal energy & Y02E10/40 \\
\hline $\begin{array}{ll}- & \text { Tower concentrators; Dish collectors; Fresnel lenses; Heat exchange systems; Trough concentrators } \\
\text { - } & \text { Conversion of thermal power into mechanical power, e.g. Rankine, Stirling solar thermal engines; Thermal updraft } \\
\text { - } & \text { Mountings or tracking }\end{array}$ & Y02E10/40-47 \\
\hline 4.1.3. Solar photovoltaic (PV) energy & Y02E10/50 \\
\hline $\begin{array}{ll}\text { - } & \text { PV systems with concentrators } \\
\text { - } & \text { Material technologies: CulnSe2 material PV cells; Dye sensitized solar cells; Solar cells from Group II-VI materials; Solar } \\
\text { cells from Group III-V materials; Microcrystalline silicon PV cells; Polycrystalline silicon PV cells; Monocrystalline silicon } \\
\text { PV cells; Amorphous silicon PV cells; Organic PV cells } \\
\text { - Power conversion electric or electronic aspects: for grid-connected applications; concerning power management inside } \\
\text { the plant, e.g. battery (dis)charging, operation, hybridisation; Maximum power point tracking [MPPT] systems }\end{array}$ & Y02E10/50-58 \\
\hline 4.1.4. Solar thermal-PV hybrids & Y02E10/60 \\
\hline 4.1.5. Geothermal energy & Y02E10/10 \\
\hline $\begin{array}{ll}- & \text { Earth coil heat exchangers; Compact tube assemblies, e.g. geothermal probes } \\
- & \text { Systems injecting medium directly into ground, e.g. hot dry rock system, underground water } \\
- & \text { Systems injecting medium into a closed well } \\
- & \text { Systems exchanging heat with fluids in pipes, e.g. fresh water or waste water } \\
\end{array}$ & Y02E10/10-18 \\
\hline 4.1.6. Marine energy & Y02E10/30 \\
\hline $\begin{array}{ll}- & \text { Oscillating water column [OWC] } \\
- & \text { Ocean thermal energy conversion [OTEC] } \\
- & \text { Salinity gradient } \\
- & \text { Wave energy or tidal swell, e.g. Pelamis-type }\end{array}$ & Y02E10/30-38 \\
\hline 4.1.7. Hydro energy & Y02E10/20 \\
\hline $\begin{array}{ll}- & \text { Conventional, e.g. with dams, turbines and waterwheels } \\
- & \text { Tidal, stream or damless hydropower, e.g. sea flood and ebb, river, stream }\end{array}$ & Y02E10/20-28 \\
\hline 4.2. ENERGY GENERATION FROM FUELS OF NON-FOSSIL ORIGIN & Y02E50 \\
\hline 4.2.1. Biofuels & Y02E50/10 \\
\hline $\begin{array}{ll}- & \text { CHP turbines for biofeed; Gas turbines for biofeed } \\
- & \text { Bio-diesel } \\
- & \text { Bio-pyrolysis; Torrefaction of biomass } \\
- & \text { Cellulosic bio-ethanol; Grain bio-ethanol; Bio-alcohols produced by other means than fermentation }\end{array}$ & Y02E50/10-18 \\
\hline 4.2.2. Fuel from waste & Y02E50/30 \\
\hline $\begin{array}{ll}- & \text { Synthesis of alcohols or diesel from waste including a pyrolysis and/or gasification step } \\
- & \text { Methane production by fermentation of organic by-products, e.g. sludge; Methane from landfill gas }\end{array}$ & Y02E50/30-346 \\
\hline 4.3. COMBUSTION TECHNOLOGIES WITH MITIGATION POTENTIAL (e.g. using fossil fuels, biomass, waste, etc.) & Y02E20 \\
\hline 4.3.1. Technologies for improved output efficiency (Combined heat and power, combined cycles, etc.) & Y02E20/10-185 \\
\hline Heat utilisation in combustion or incineration of waste & Y02E20/12 \\
\hline Combined heat and power generation [CHP] & Y02E20/14 \\
\hline Combined cycle power plant [CCPP], or combined cycle gas turbine [CCGT] & Y02E20/16 \\
\hline Integrated gasification combined cycle [IGCC] & Y02E20/18 \\
\hline combined with carbon capture and storage [CCS] & Y02E20/185 \\
\hline
\end{tabular}




\section{ENV/WKP(2015)10}

\begin{tabular}{|c|c|}
\hline 4.3.2. Technologies for improved input efficiency (Efficient combustion or heat usage) & Y02E20/30-366 \\
\hline $\begin{array}{ll}- & \text { Direct } \mathrm{CO} 2 \text { mitigation: Use of synair, i.e. a mixture of recycled } \mathrm{CO} 2 \text { and pure } \mathrm{O} 2 \text {; Use of reactants before or during } \\
\text { combustion; Segregation from fumes, including use of reactants downstream from combustion or deep cooling; Controls } \\
\text { of combustion specifically inferring on } \mathrm{CO} 2 \text { emissions } \\
\text { - } \quad \text { Indirect } \mathrm{CO} 2 \text { mitigation, i.e. by acting on non } \mathrm{CO} 2 \text { directly related matters of the process, e.g. more efficient use of fuels: } \\
\text { Cold flame; Oxyfuel combustion; Unmixed combustion; Air pre-heating } \\
\text { - } \quad \text { Heat recovery other than air pre-heating: at fumes level, at burner level }\end{array}$ & \\
\hline 4.4. NUCLEAR ENERGY & Y02E30 \\
\hline \multicolumn{2}{|l|}{ 4.4.1. Nuclear fusion reactors } \\
\hline $\begin{array}{ll}\text { - } & \text { Magnetic plasma confinement [MPC]: Tokamaks; Stellarators; Other reactors with MPC; First wall, divertor, blanket } \\
- & \text { Inertial plasma confinement: Injection systems and targets } \\
\text { - } & \text { Low temperature fusion, e.g. "cold fusion" }\end{array}$ & Y02E 30/10-18 \\
\hline \multicolumn{2}{|l|}{ 4.4.2. Nuclear fission reactors } \\
\hline $\begin{array}{ll} & \text { Boiling water reactors; Pressurized water reactors; Gas cooled reactors; Fast breeder reactors; Liquid metal reactors; } \\
& \text { Pebble bed reactors; Accelerator driven reactors } \\
- & \text { Fuel } \\
- & \text { Control of nuclear reactions } \\
- & \text { Other aspects relating to nuclear fission }\end{array}$ & Y02E 30/30-40 \\
\hline 4.5. TECHNOLOGIES FOR AN EFFICIENT ELECTRICAL POWER GENERATION, TRANSMISSION OR DISTRIBUTION & Y02E40 \\
\hline 4.5.1. Superconducting electric elements or equipment & Y02E40/60-69 \\
\hline $\begin{array}{ll}- & \text { Superconducting generators: Superconducting synchronous generators; Superconducting homopolar generators } \\
- & \text { Superconducting transmission lines or power lines or cables or installations thereof } \\
- & \text { Superconducting transformers or inductors } \\
- & \text { Superconducting energy storage for power networks, e.g. SME, superconducting magnetic storage } \\
- & \text { Protective or switching arrangements for superconducting elements or equipment } \\
- & \text { Current limitation using superconducting elements, including multifunctional current limiters } \\
\end{array}$ & \\
\hline \multicolumn{2}{|l|}{ 4.5.2. Not elsewhere classified } \\
\hline $\begin{array}{cl}\text { Flexible AC transmission systems [FACTS] } \\
- & \text { Static VAR compensators [SVC], static VAR generators [SVG] or static VAR systems [SVS], including thyristor-controlled } \\
& \text { reactors [TCR], thyristor-switched reactors [TSR] or thyristor-switched capacitors [TSC] } \\
- & \text { Thyristor-controlled series capacitors [TCSC] } \\
- & \text { Static synchronous compensators [STATCOM] } \\
- & \text { Unified power flow controllers [UPF] or controlled series voltage compensators } \\
\end{array}$ & Y02E40/10-18 \\
\hline $\begin{array}{ll}\text { Active power filtering [APF] } \\
-\quad \text { Non-specified or voltage-fed active power filters } \\
-\quad \text { Current-fed active power filters; using a multilevel or multicell converter }\end{array}$ & Y02E40/20-26 \\
\hline $\begin{array}{l}\text { Reactive power compensation } \\
\quad-\quad \text { Reactive power compensation; using synchronous generators; for voltage regulation }\end{array}$ & Y02E40/30-34 \\
\hline Arrangements for reducing harmonics & Y02E40/40 \\
\hline Arrangements for eliminating or reducing asymmetry in polyphase networks & Y02E40/50 \\
\hline $\begin{array}{l}\text { Smart grids } \\
-\quad \text { Systems characterised by the monitoring, control or operation of energy generation units, e.g. distributed generation } \\
\text { [DER] or load-side generation; Systems characterised by the monitoring, control or operation of flexible AC transmission } \\
\text { systems [FACTS] or power factor or reactive power compensating or correcting units; Computing methods or systems for } \\
\text { efficient or low carbon management or operation of electric power systems }\end{array}$ & Y02E40/70 \\
\hline 4.6. ENABLING TECHNOLOGIES (Technologies with potential or indirect contribution to emissions mitigation) & Y02E60 \\
\hline 4.6.1. Energy storage & Y02E60/10-17 \\
\hline 4.6.1.1. Batteries & Y02E60/12 \\
\hline $\begin{array}{ll}- & \text { Lithium-ion batteries } \\
- & \text { Alkaline secondary batteries, e.g. NiCd or NiMH } \\
- & \text { Lead-acid batteries } \\
- & \text { Hybrid cells }\end{array}$ & \\
\hline
\end{tabular}


ENV/WKP(2015)10

\begin{tabular}{|c|c|}
\hline 4.6.1.2. Capacitors & Y02E60/13 \\
\hline - Ultracapacitors, supercapacitors, double-layer capacitors & \\
\hline 4.6.1.3. Thermal storage & Y02E60/14 \\
\hline - Sensible heat storage, Latent heat storage, Cold storage & \\
\hline 4.6.1.4. Pressurised fluid storage & Y02E60/15 \\
\hline 4.6.1.5. Mechanical storag & Y02E60/16 \\
\hline - Mechanical energy storage, e.g. flywheels & \\
\hline 4.6.1.6. Pumped storage & Y02E60/17 \\
\hline 4.6.2. Hydrogen technology & Y02E60/30-368 \\
\hline $\begin{array}{l}\text { - Hydrogen storage: Storage of liquefied, solidified, or compressed hydrogen in containers; Storage in caverns; Reversible } \\
\text { uptake of hydrogen by an appropriate medium (e.g. carbon, metal, rare earth metal, metal alloy, organic compound) } \\
\text { - } \quad \text { Hydrogen distribution } \\
\text { - } \quad \text { Hydrogen production from non-carbon containing sources: by chemical reaction with metal hydrides, e.g. hydrolysis of } \\
\text { metal borohydrides; by decomposition of inorganic compounds, e.g. splitting of water other than electrolysis, ammonia } \\
\text { borane; by electrolysis of water; by photo-electrolysis }\end{array}$ & \\
\hline 4.6.3. Fuel cells & Y02E60/50-566 \\
\hline $\begin{array}{ll}\text { - } & \text { Fuel cells } \\
\text { - } & \text { characterised by type or design: Proton Exchange Membrane Fuel Cells [PEMFC], Direct Alcohol Fuel Cells [DAFC], } \\
& \text { Direct Methanol Fuel Cells [DMFC]; Solid Oxide Fuel Cells [SOFC]; Molten Carbonate Fuel Cells [MCFC]; Bio Fuel Cells; } \\
& \text { Regenerative or indirect fuel cells, e.g. redox flow type batteries } \\
\text { - } & \text { integrally combined with other energy production systems: Cogeneration of mechanical energy, e.g. integral combination } \\
& \text { of fuel cells and electric motors; Production of chemical products inside the fuel cell; incomplete combustion }\end{array}$ & \\
\hline 4.6.4. Smart grids in the energy sector & Y02E60/70 \\
\hline $\begin{array}{l}\text { Systems integrating technologies related to power network operation and communication or information technologies } \\
\text { mediating in the improvement of the carbon footprint of electrical power generation, transmission or distribution, i.e. smart } \\
\text { grids as enabling technology in the energy generation sector }\end{array}$ & Y02E60/70-7892 \\
\hline 4.7. OTHER ENERGY CONVERSION OR MANAGEMENT SYSTEMS REDUCING GHG EMISSIONS & Y02E70 \\
\hline $\begin{array}{ll}\text { - } & \text { Hydrogen from electrolysis with energy of non-fossil origin, e.g. PV, wind power, nuclear } \\
- & \text { Systems combining fuel cells with production of fuel of non-fossil origin } \\
- & \text { Systems combining energy storage with energy generation of non-fossil origin } \\
- & \text { Energy efficient batteries, ultracapacitors, supercapacitors or double-layer capacitors charging or discharging systems or } \\
& \text { methods, e.g. auxiliary power consumption reduction, resonant chargers or dischargers, resistive losses minimisation }\end{array}$ & \\
\hline
\end{tabular}

\begin{tabular}{|c|c|}
\hline 5. CAPTURE, STORAGE, SEQUESTRATION OR DISPOSAL OF GREENHOUSE GASES & Y02C \\
\hline 5.1. CO2 CAPTURE OR STORAGE (CCS) & Y02C10 \\
\hline $\begin{array}{ll}- & \text { Capture by biological separation } \\
- & \text { Capture by chemical separation } \\
- & \text { Capture by absorption } \\
- & \text { Capture by adsorption } \\
- & \text { Capture by membranes or diffusion } \\
- & \text { Capture by rectification and condensation } \\
- & \text { Subterranean or submarine } \mathrm{CO} 2 \text { storage } \\
\end{array}$ & Y02C10/00-14 \\
\hline 5.2. CAPTURE OR DISPOSAL OF GREENHOUSE GASES OTHER THAN CO2 & Y02C20 \\
\hline $\begin{array}{ll}- & \text { of nitrous oxide (N2O) } \\
- & \text { of methane } \\
- & \text { of perfluorocarbons [PFC], hydrofluorocarbons [HFC] or sulfur hexafluoride [SF6] }\end{array}$ & $\mathrm{Y} 02 \mathrm{C} 20 / 00-30$ \\
\hline
\end{tabular}


ENV/WKP(2015)10

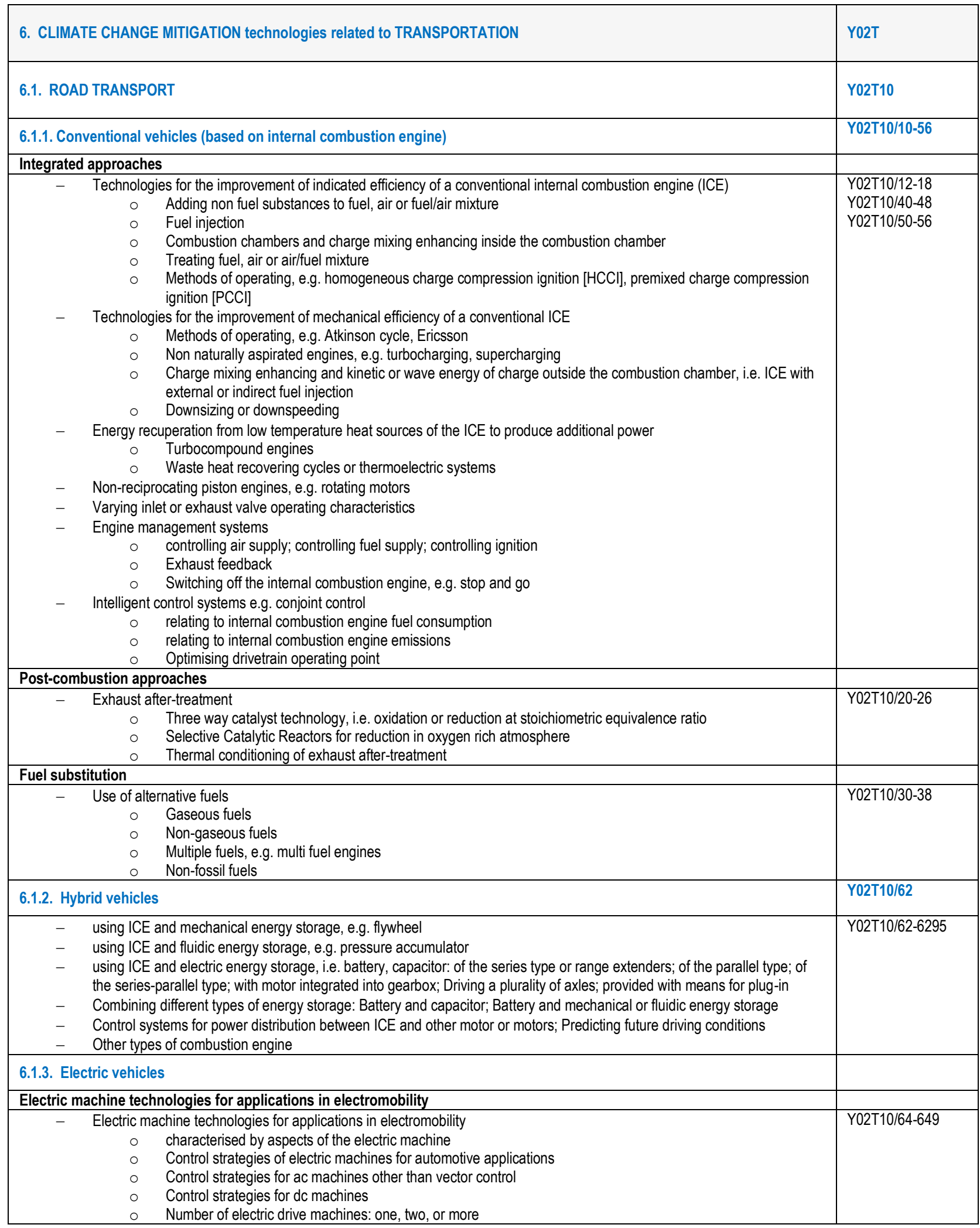


ENV/WKP(2015)10

\begin{tabular}{|c|c|c|c|}
\hline \multicolumn{3}{|c|}{ Energy storage for electromobility } & \\
\hline \multicolumn{3}{|c|}{ Energy storage for electromobility } & Y02T10/70-7094 \\
\hline & & \\
\hline & & , supercapacitors or ultracapacitors & \\
\hline & \multicolumn{2}{|c|}{ Mechanical energy storage devices, e.g. flywheels } & \\
\hline & \multicolumn{2}{|c|}{ Energy storage management } & \\
\hline & \multicolumn{2}{|r|}{$\begin{array}{l}\text { Electromobility-specific charging systems or methods for batteries, ultracapacitors, supercapacitors or double-layer } \\
\text { capacitors }\end{array}$} & \\
\hline \multicolumn{3}{|c|}{ Electric energy management in electromobility } & \\
\hline \multirow{7}{*}{\multicolumn{3}{|c|}{$\begin{array}{cc}\text { Electric energy management in electromobility } \\
-\quad \text { Electric power conversion within the vehicle } \\
-\quad \text { Optimisation of vehicle performance } \\
\circ & \text { Automated control } \\
\circ & \text { Desired performance achievement } \\
\circ & \text { Optimisation of energy management } \\
\circ & \text { Route optimisation } \\
\end{array}$}} & Y02T10/72-7291 \\
\hline & & & \\
\hline & & & \\
\hline & & & \\
\hline & & & \\
\hline & & & \\
\hline & & & \\
\hline \multicolumn{3}{|c|}{ 6.1.4. Fuel efficiency-improving vehicle design (common to all road vehicles) } & \\
\hline \multicolumn{3}{|c|}{$\begin{array}{cl}\text { Technologies aiming to reduce greenhouse gas (GHG) emissions common to all road transportation technologies } \\
-\quad \text { Tools or systems for aerodynamic design } \\
-\quad \text { Data processing systems or methods, management, administration } \\
-\quad \text { Optimisation of rolling resistance: Tyres, e.g. materials, shape; Bearings; Others, e.g. wheel construction } \\
-\quad \text { Optimized components or subsystems e.g. lighting, actively controlled glasses } \\
-\quad \text { Energy harvesting concepts as power supply for auxiliaries' energy consumption e.g. photovoltaic sun-roof } \\
-\quad \text { Energy efficient charging or discharging systems for batteries, ultracapacitors, supercapacitors or double-layer capacitors } \\
\quad \text { specially adapted for vehicles } \\
-\quad \text { Energy-efficient charging or discharging systems for batteries, ultracapacitors, supercapacitors or double-layer capacitors } \\
\quad \text { adapted for road vehicles }\end{array}$} & $\begin{array}{l}\text { Y02T10/80-86 } \\
\text { Y02T10/90-92 }\end{array}$ \\
\hline \multicolumn{3}{|c|}{ 6.2. RAIL TRANSPORT } & Y02Т30 \\
\hline \multicolumn{3}{|c|}{ 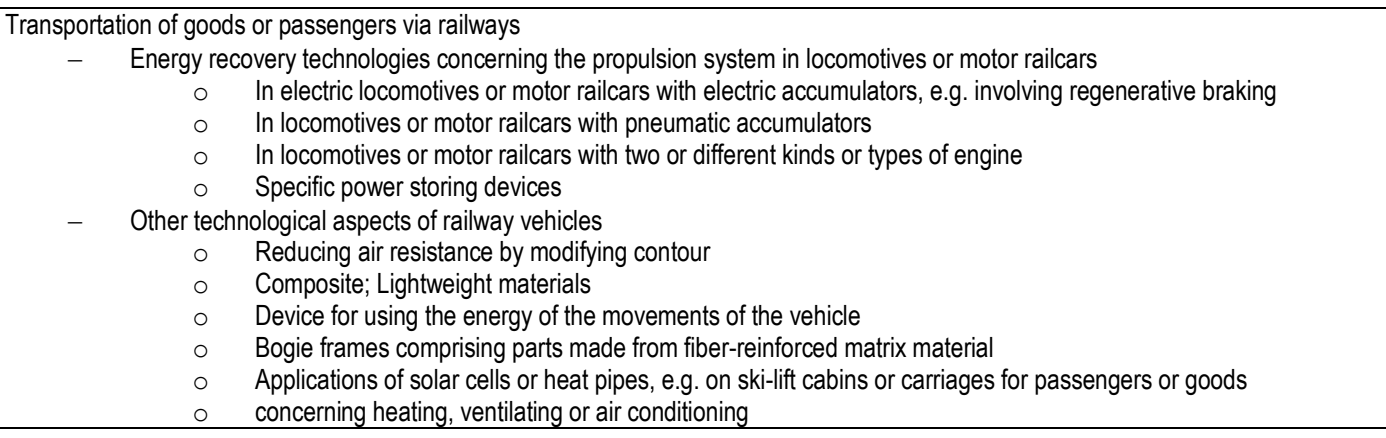 } & Y02T30/00-42 \\
\hline \multicolumn{3}{|c|}{ 6.3. AIR TRANSPORT } & Y02T50 \\
\hline \multicolumn{3}{|c|}{ 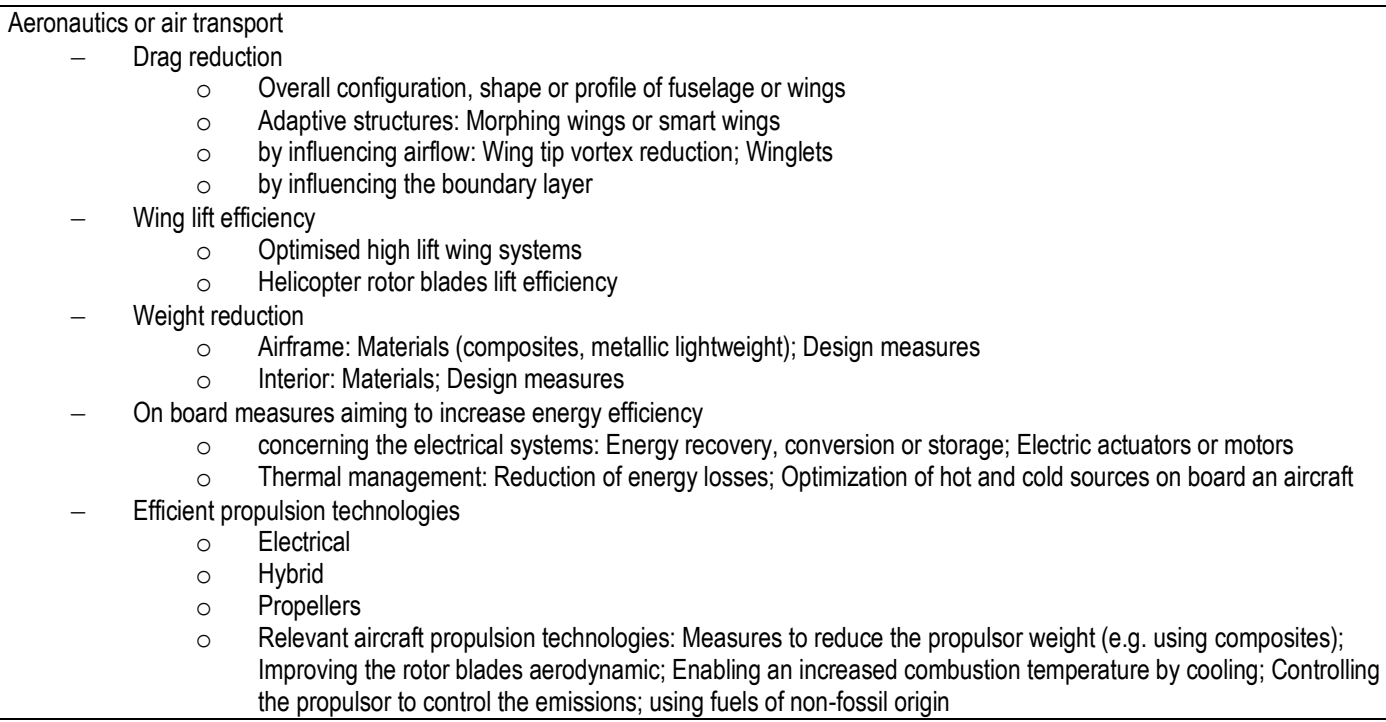 } & Y02T50/00-90 \\
\hline
\end{tabular}


ENV/WKP(2015)10

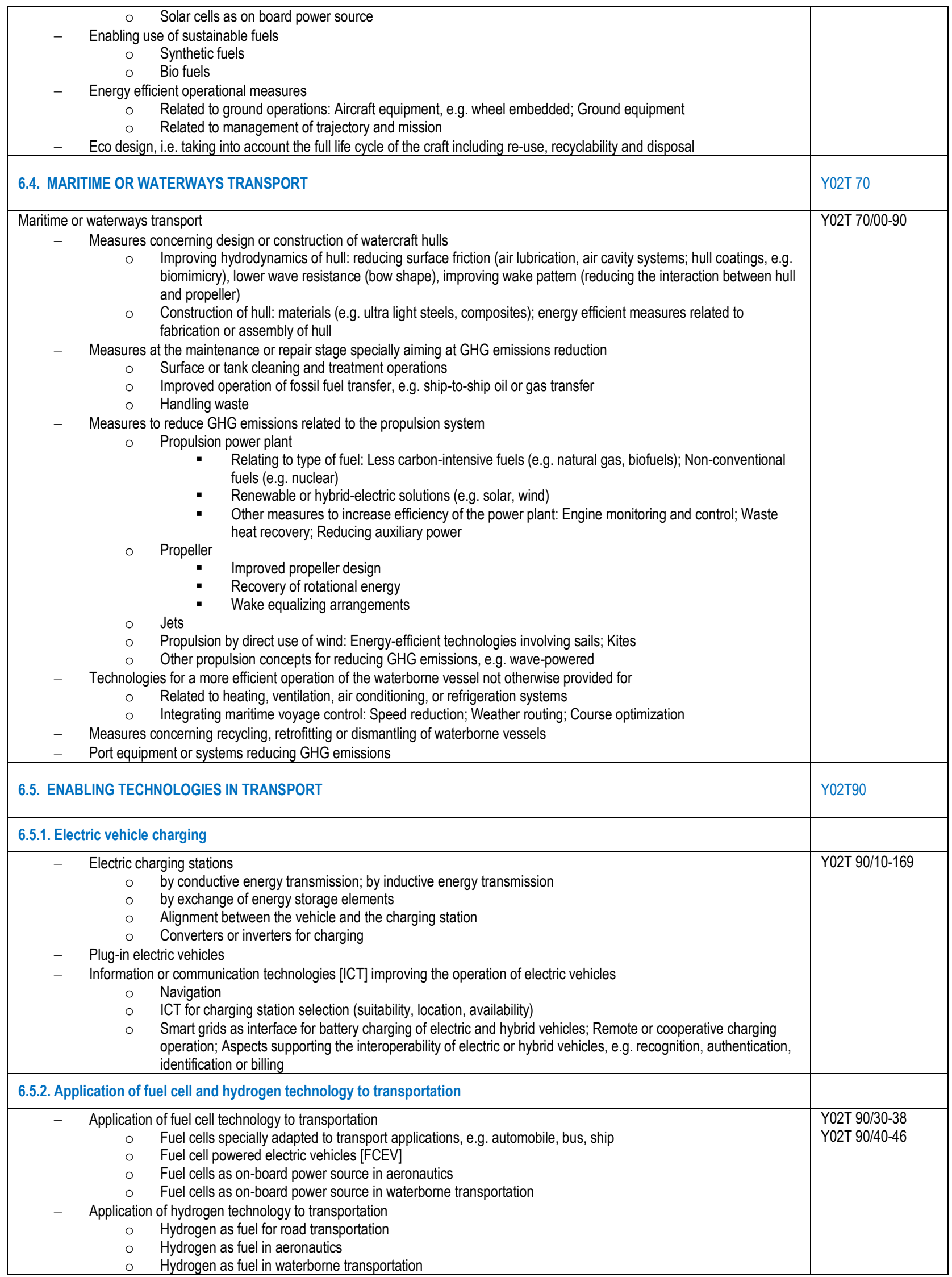


ENV/WKP(2015)10

\begin{tabular}{|c|c|c|}
\hline \multicolumn{2}{|c|}{ 7. CLIMATE CHANGE MITIGATION technologies related to BUILDINGS } & Y02B \\
\hline \multicolumn{2}{|c|}{ 7.1. INTEGRATION OF RENEWABLE ENERGY SOURCES IN BUILDINGS } & Y02B10 \\
\hline & $\begin{array}{l}\text { Photovoltaic [PV]: Roof systems for PV cells; PV hubs } \\
\text { Solar thermal: Evacuated solar collectors; Air conditioning or refrigeration systems } \\
\text { Wind power } \\
\text { Geothermal heat-pumps } \\
\text { Hydropower in dwellings } \\
\text { Use of biomass for heating } \\
\text { Hybrid systems; Uninterruptible or back-up power supplies integrating renewable energies }\end{array}$ & Y02B 10/00-72 \\
\hline \multicolumn{2}{|c|}{ 7.2. ENERGY EFFICIENCY IN BUILDINGS } & \\
\hline \multicolumn{2}{|c|}{ 7.2.1. Lighting } & Y02B20 \\
\hline \multicolumn{2}{|r|}{$\begin{array}{ll}\text { Energy-efficient lighting: } \\
-\quad \text { Energy saving technologies for incandescent lamps, e.g. halogen lamps } \\
-\quad \text { Gas discharge lamps, e.g. fluorescent lamps, high-intensity discharge lamps [HID], or molecular radiators } \\
-\quad \text { Semiconductor lamps, e.g. solid state lamps [SSL], light emitting diodes [LED], or organic LED [OLED] } \\
-\quad \text { Control techniques providing energy savings, e.g. timing or schedule, detection of the user, detection of the illumination } \\
& \text { level } \\
- & \text { Used in particular applications (e.g. in street lighting) }\end{array}$} & Y02B 20/00-72 \\
\hline \multicolumn{2}{|c|}{ 7.2.2. Heating, ventilation or air conditioning [HVAC] } & Y02B30 \\
\hline \multicolumn{2}{|r|}{ 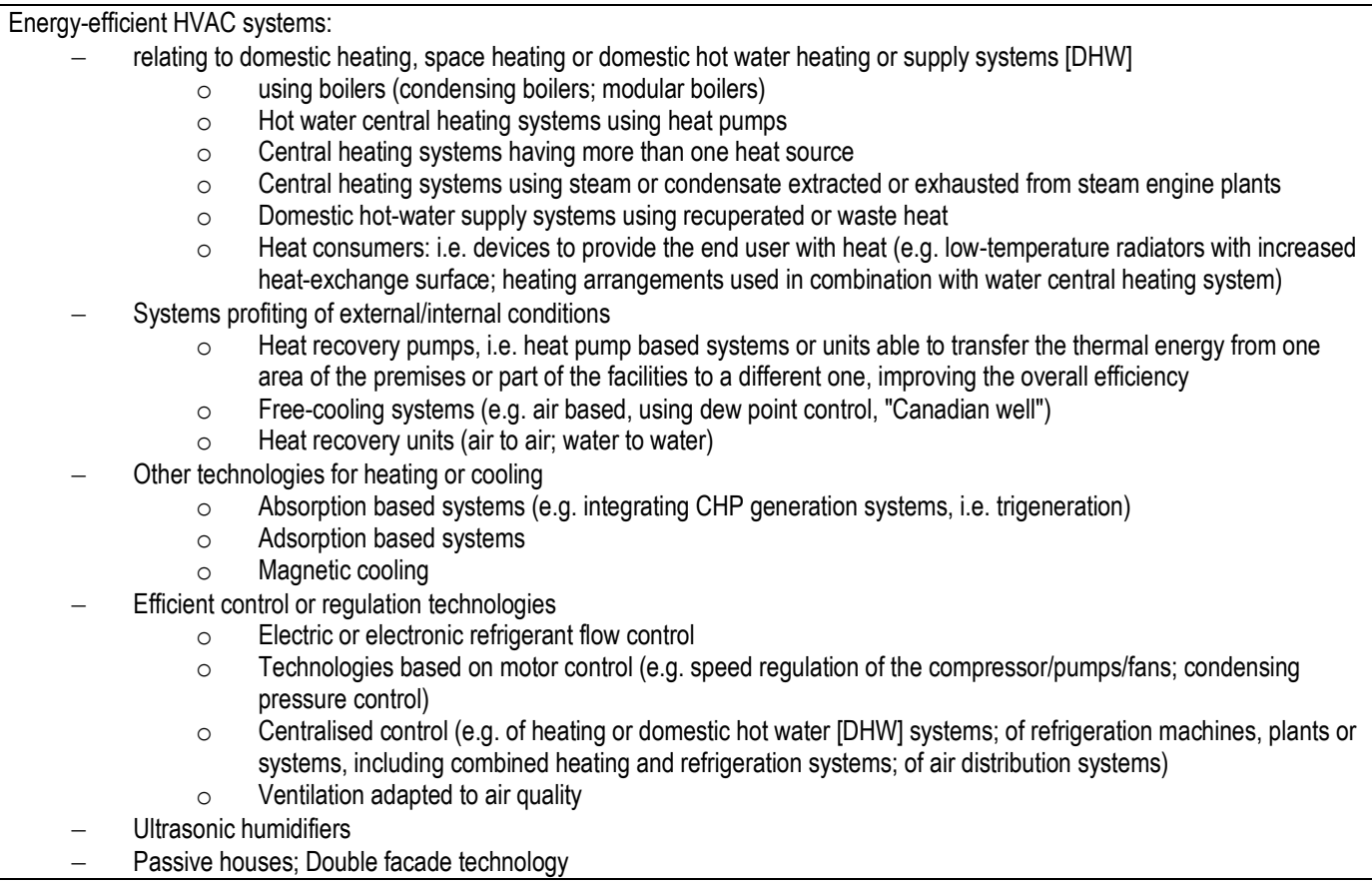 } & Y02B 30/00-94 \\
\hline \multicolumn{2}{|c|}{ 7.2.3. Home appliances } & Y02B40 \\
\hline \multicolumn{2}{|r|}{ 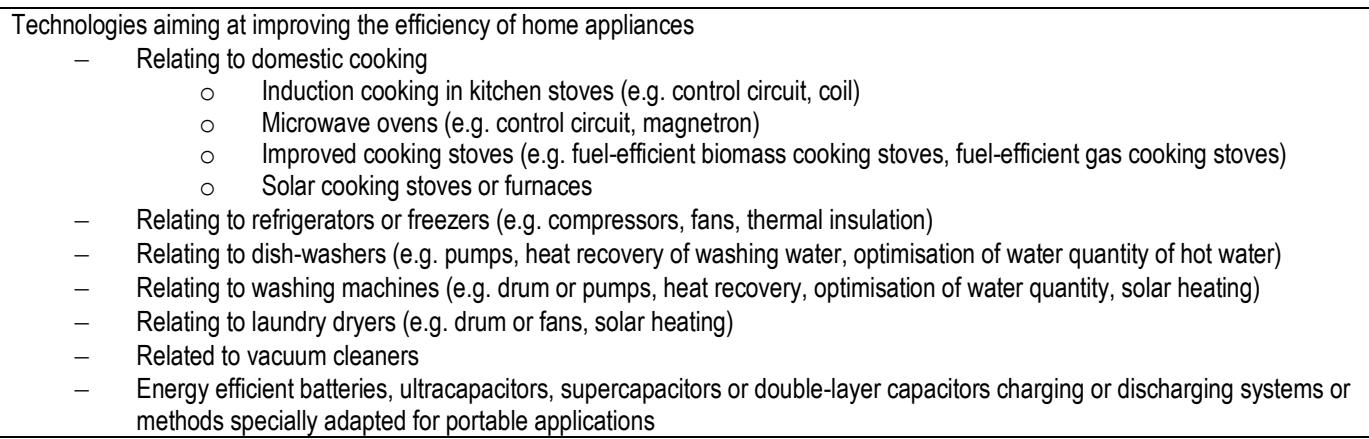 } & Y02B 40/00-90 \\
\hline
\end{tabular}


ENV/WKP(2015)10

\begin{tabular}{|c|c|c|c|}
\hline \multicolumn{3}{|c|}{ 7.2.4. Elevators, escalators and moving walkways } & Y02B50 \\
\hline \multicolumn{3}{|c|}{ 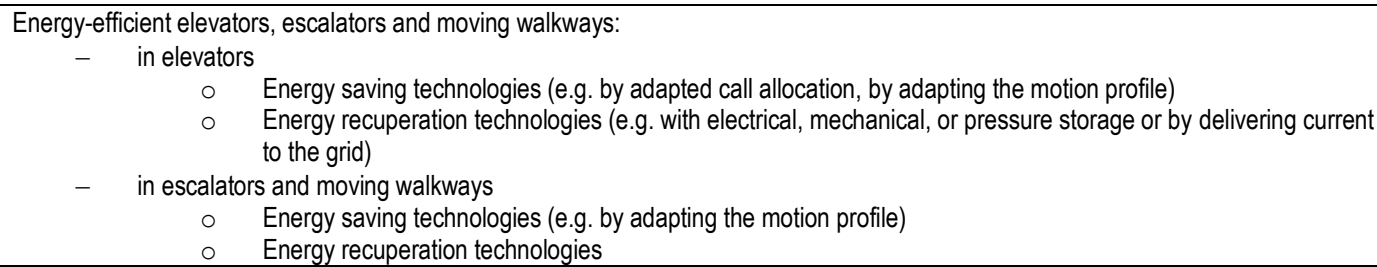 } & Y02B 50/00-24 \\
\hline \multicolumn{3}{|c|}{ 7.2.5. Information and communication technologies } & Y02B60 \\
\hline \multicolumn{3}{|c|}{ 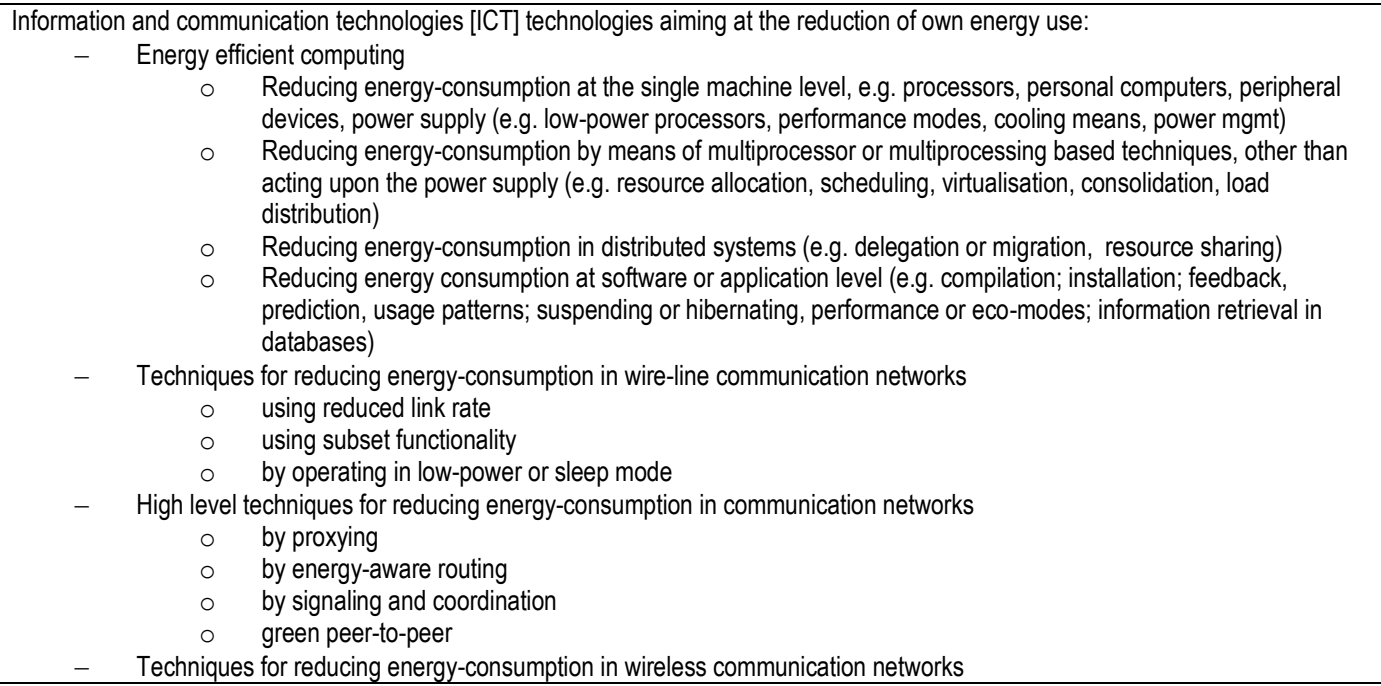 } & Y02B 60/00-50 \\
\hline \multicolumn{3}{|c|}{ 7.2.6. End-user side } & Y02B70 \\
\hline \multicolumn{3}{|c|}{$\begin{array}{l}\text { Technologies for an efficient end-user side electric power management and consumption: } \\
-\quad \text { Technologies improving the efficiency by using switched-mode power supplies, i.e. efficient power electronics conversion } \\
\circ \text { Power factor correction technologies for power supplies } \\
\circ \text { Reduction of losses in power supplies } \\
\circ \text { Efficient standby or energy saving modes, e.g. detecting absence of load or auto-off } \\
\text { - Systems integrating technologies related to power network operation and ICT for improving the carbon footprint, i.e. smart } \\
\text { grids supporting the management or operation of end-user stationary applications } \\
\circ \quad \text { End-user application control systems (e.g. load shedding, peak shaving, other demand response systems; } \\
\text { domotics or building automation systems) } \\
\text { Smart metering supporting the carbon neutral operation of end-user applications in buildings } \\
\text { - Systems which determine the environmental impact of user behaviour } \\
\text { - Systems which monitor performance of renewable electricity generating systems, e.g. solar panels }\end{array}$} & Y02B 70/00-346 \\
\hline \multicolumn{3}{|c|}{ 7.3. ARCHITECTURAL OR CONSTRUCTIONAL ELEMENTS IMPROVING THE THERMAL PERFORMANCE OF BUILDINGS } & Y02B80 \\
\hline \multicolumn{3}{|c|}{$\begin{array}{cl}\text { Architectural or constructional elements improving the thermal performance of buildings: } \\
-\quad \text { Insulation (e.g. slab shaped vacuum insulation, aerogel insulation) } \\
-\quad \text { Windows or doors (e.g. vacuum glazing, aerogel) } \\
-\quad \text { Roofs (e.g. roof garden systems, roof coverings with high solar reflectance) } \\
-\quad \text { Floors specially adapted for storing heat or cold } \\
-\quad \text { Light-dependent control systems for sun shading }\end{array}$} & Y02B 80/00-50 \\
\hline \multicolumn{3}{|c|}{ 7.4. ENABLING TECHNOLOGIES IN BUILDINGS } & Y02B90 \\
\hline \multicolumn{3}{|c|}{ 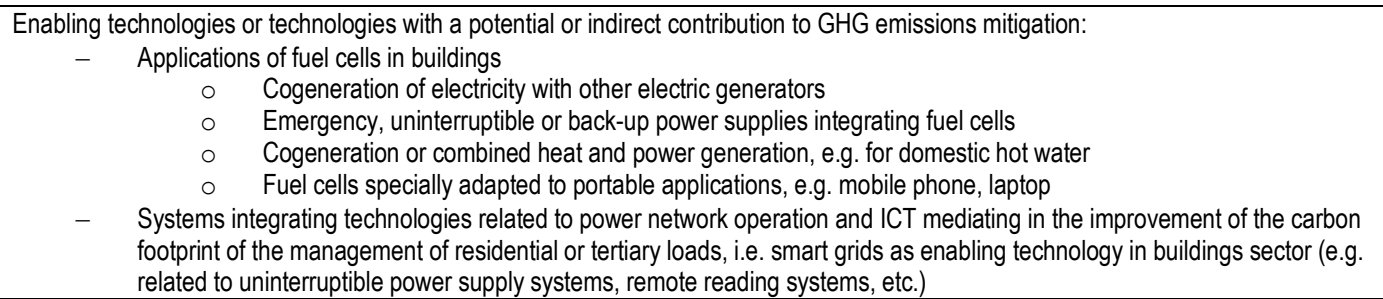 } & Y02B 90/00-2692 \\
\hline
\end{tabular}

